\title{
SPECIALIZATION IN CRIMINAL LAW
}

\author{
Michael. H. KaHN* \\ Lisa Davidson KahN $\dagger$
}

\section{INTRODUCTION: \\ The ABA and Legal Specialization}

Admission to the bar has traditionally been considered synonomous with the ability to render effective legal assistance on every variety of legal problem. ${ }^{1}$ This assumption was more nearly valid in the early days of American jurisprudence when the typical legal problem involved no more than basic property law, admiralty, or simple commercial situations. ${ }^{2}$ When the Canons of Ethics were adopted in 1908, the American Bar Association (ABA) maintained that the lawyer was a client's lawyer, as opposed to a problem lawyer, and could be expected to handle any task set before him by his client. Strong anti-advertising strictures were therefore included in the Canons on the theory that there was no need to inform other lawyers, much less the public, of an area of proficiency that a lawyer might want to claim. ${ }^{3}$

By the middle of the twentieth century, the ABA was forced to turn its attention towards specialization in order to compensate for the growing complexity and diversity of American life. ${ }^{4}$ It had become ultimately impossible for any one lawyer to keep pace with the vast amount of continually emerging case reports, articles, books, legislation, and special studies which encompassed a multitude of legal issues. Individual lawyers were already limiting their practice and large law firms were departmentalizing. The question for the ABA became not whether to have specialists but whether to formalize and regulate specialization.

In 1952, the ABA organized the first "Committee on Continuing Legal Education," which concluded that de facto specialization existed, that specialization required further study, and that it should be ultimately recognized by the $\mathrm{ABA}^{5}{ }^{5}$ Since then the ABA has moved less conclusively. ${ }^{6}$

* J.D. 1977, Duke University School of Law.

$\dagger$ J.D. 1977, Duke University School of Law.

1. See Burger, The Special Skills of Advocacy, 42 Fordham L. Rev. 227 at 231 (1973).

2. Unpublished address by $\mathrm{D}$. Fromson, The Challenge of Specialization-Professionalism at the Crossroads at 3, presented to the House of Delegates, NYSB Ass'n, June 18, 1976, on file with NYSB Ass'n.

3. Joiner, Specialization in the Law, 48 FLA. B.J. 163 at 164 (1974).

4. D. Fromson, supra note 2 , at 7 .

5. D. Fromson, supra note 2 , at 8 .

6. In 1953 the Committee on Specialization and Specialized Legal Education was appointed by 
In 1967, a special committee was appointed to study the information relevant to specialization and to prepare a prototype for consideration by the ABA Board of Governors and House of Delegates. The committee determined in 1969 that it was not desirable at that time to establish such a national plan, and that further consideration should be deferred until several state prototypes had been implemented and could be subsequently examined. ${ }^{7}$

the ABA. This Committee asserted the necessity of regulating voluntary specialization and proposed certain standards. In 1954 the ABA Board of Governors, after reviewing the proposals and recommendations of the Committee, made two acknowledgments which were basic to the problems. First, they recognized the necessity for regulating voluntary specialization. Second, they proposed that standards be establis hed.

A three-member committee was then appointed by the ABA Board of Governors. Their recommendations and proposals, which were ultimately brought before the House of Delegates, provided for:

(1) establishment of specialized fields in law along somewhat the same lines as those adopted by the American Medical Association.

(2) appointment of a Council of Legal Specialists to organize, approve, and police specialized groups. This Council would have the power, subject to the approval of the Board of Governors, to set standards for certification, including a suitable grandfather clause, to prescribe education, and otherwise to implement the plan.

When this plan came before the House of Delegates, it met vigorous opposition and was dropped. One reason for this opposition was that many attorneys resented the recognition of specialties.

In 1961, a newly formed committee, the Special Committee on Recognition and Certification in Law Practice, was formed to study the problem of specialization. The Committee submitted a plan which was also referred to the House of Delegates for approval. This plan proposed certain basic features-namely, that certification be voluntary; that certification be possible in several fields as long as the lawyer meets the standards of each specialty; that lack of certification in any particular field not limit a lawyer's practice; that designation of the specialty groups be only by an ABA Council on Certification, acting in cooperation with the various ABA Sections which would propose the fields for issuance of certificates of proficiency; and that a regulatory council with power to set standards for certification of specialists be created, but, unlike the 1954 plan, without power to police the ranks. Once again there was opposition and the plan, although finally approved, was designated "For Information Only." In 1963 the proposed program was shelved, and afterward the Special Committee, feeling that the legal profession was not ready for its proposals, was permanently disbanded.

In 1965 the Board of Governors of the ABA, pursuant to a resolution adopted by the House of Delegates in that year, charged the ABA Special Committee on Availability of Legal Services with the responsibility of studying and making recommendations with respect to the adequacy and availability of legal services. In June 1967, that Committee came to the "firm conclusion that recognition and regulation of specialization in the practice of law will measurably improve the availability of legal services to those who should be in need of them." The Committee recommended to the House of Delegates that it urge the ABA Board of Governors to renew its efforts to implement the 1954 recommendation that a procedure for recognizing and certifying specialists be established.

In August of 1967, however, the House of Delegates refused to vote, even in principle, for the Committee's recommendation. Instead it adopted an amendment to the Committee's report, the effect of which was to rescind that part of the 1954 decision approving in principle the need to regulate specialization for the protection of the public and the Bar. By this action the House of Delegates placed the whole subject of specialization back in the hands of the ABA Board of Governors. The Board of Governors in 1967 then created the Special Comnittee on Specialization. Committee on Specialization, Cal. State Bar Final Report, 44 CaL. St. B. J. 493 at 496-500 (1969).

7. Id. 
In August of 1974, the ABA committee issued a report in part stating: "We now urge states which have not begun specialization programs to forego implementing pilot programs until we have had an opportunity to evaluate these programs which are in existence or may soon be in existence." 8

Presently, the committee is evaluating these state pilot programs in light of the three acknowledged goals of specialization: (1) To provide the public with greater access to attorneys; (2) To decrease the unit costs of legal services to the client; and (3) To increase the quality of the services delivered. ${ }^{9}$ The ABA is planning a similar evaluation of the specialization programs of California, New Mexico, and possibly one other state. It is anticipated that this study will be completed in 1978 or $1979 .^{10}$

As of January 1977, four states had implemented specialization plans ${ }^{11}$ and one state had a plan approved and ready for implementation. ${ }^{12}$ Seventeen other states had prepared plans which lacked approval either by the state bar association or the state supreme court. ${ }^{13}$ Two states were working on plans, ${ }^{14}$ and eighteen states and the District of Columbia were continuing to study the issue through designated committees. ${ }^{15}$ Eight states were doing no work on specialization at all. ${ }^{16}$

The plans of the four states which have approved specialization plans in operation may be catagorized under three headings. One is the program of certification which was adopted first by California, and then by Texas (which patterned its program after that of California). ${ }^{17}$ A second approach, that of New Mexico, is the self-designation or self-identification plan. ${ }^{18}$ The third ap-

\footnotetext{
8. Id.

9. D. Fromson, supra note 2 , at 27,28

10. Id.

11. California, Texas, New Mexico, Florida

12. Washington.

13. Alaska, Arizona, Colorado, Connecticut, Indiana, Kentucky, Massachusetts, Minnesota, Missouri, Nebraska, Nevada, New Hampshire, New Jersey, Oklahoma, Oregon, South Carolina, Wisconsin.

14. Idaho and Illinois.

15. Alabama, Arkansas, Delaware, Georgia, Iowa, Kansas, Louisiana, Maine, Michigan, New York, North Carolina, North Dakota, South Dakota, Tennessee, Utah, Vermont, and Virginia.

16. Hawaii, Maryland, Mississippi, Montana, Pennsylvania, Rhode Island, West Virginia, and Wyoming

17. California Board of Legal Specialization, Rules and Regulations of the California Board of Legal Specialization and Standards for Certification and Recertification of Criminal Law Specialists, on file with California Board of Legal Specialization, San Francisco [hereinafter cited as California Plan, Rules and Regulations and California Plan, StanDARDS respectively].

18. A Plan for Recognition of Specialization and limiting of Law Practice, approved by New Mexico Supreme Court, July 10, 1973, 85 N. Mex. XXXV (1973), and New Mexico State Bar Code of Professional Responsibility-Canons and Disciplinary Rules (effective July 1, 1974), Rule 2-105, on file with the Specialization Board, New Mexico Law Center, Albuquerque [hereinafter cited as NEw Mexico Plan and New Mexico Code of Professional Responsibility respectively.]
} 
proach is Florida's plan which attempts to incorporate the most effective facets of both the certification and self-designation approaches. ${ }^{19}$

\section{1}

The Role of Counsel in the Criminal Justice System

\section{A. The Necessity of Qualified Criminal Law Counsel}

Illinois Supreme Court Justice Schafaer has stated that, "Of all the rights that an accused person has, the right to be represented by counsel is by far the most pervasive, for it affects his ability to assert any other rights he may have."20 The United States Supreme Court has repeatedly recognized the importance of adequate counsel for a criminal defendant, stating that the defendant "requires the guiding hand of counsel at every step in the proceedings against him. Without it, though he be not guilty, he faces the danger of conviction because he does not know how to establish his innocence."21

The United States Court of Appeals for the district of Columbia has explicitly found, ${ }^{22}$ and the Supreme Court has implied ${ }^{23}$ that the right to effective assistance, like the right to counsel, emanates from the Sixth Amendment, as well as from the due process clause. The Supreme Court has observed that the purpose of counsel is to "preserve the adversary process" 24 and that counsel's role is that of an "active advocate in behalf of his client." 25 Obviously, a competent prosecutor is equally demanded by these tenets a just conviction being as important to the public welfare as a just aquittal. ${ }^{26}$ Thus the prosecutor has a responsibility to the public to effect law enforcement, as well as the responsibility to respect the rights of the accused..$^{27}$

Broader ethical considerations reinforce the demand for competent prosecutorial and defense counsel. Bestowed with a monopoly on the provision of legal services, the legal profession is obligated to provide these services in the public trust. $^{28}$ The Code of Professional Responsibility makes the self-evident

19. Florida Bar Bylaws, Art. VIII, Florida Designation Plan, approved by the Florida Supreme Court, June 4, 1975, In re Florida Bar, __ Fla.__, 319 So.2d 1 (1975) (hereinafter cited as Florida PlaN].

20. Schaefer, Federalism and State Criminal Procedure, 70 HaRv. L. REv. 1, 8 (1956).

21. Powell v. Alabama, 287 U.S. 45, 69 (1932).

22. Scott v. United States, 427 F.2d 609, 610 (D.C. Cir. 1970); see United States v. DeCoster, 487 F.2d 1 197, 1202 (D.C. Cir. 1973).

23. United States v. Wade, 388 U.S. 218, 227 (1967); see United States v. DeCoster, 487 F.2d 1197 (D.C. Cir. 1973).

24. United States v. Ash, 413 U.S. 300 (1973)

25. Anders v. California, 386 U.S. 738,744 (1967).

26. Burger, supra note 1 , at 237.

27. A.B.A. Project on Standards for Criminal Justice, The Prosecution function and The Defense Function 19, 20 (1971).

28. Brickman, Of Arterial Passageways Through the Legal Process: The Right of Universal Access to Courts and Lawyering Services, 48 N.Y.U. L. REv. 595 (1973). 
observation that an attorney should not undertake to perform a legal matter which he knows or should know is not within his area of competence without associating with an attorney who is competent in that field.$^{29}$ Idealistic as it may be in light of current case loads, the moral issue is the most compelling one; as the public is expected to abide by the law, the legal profession must provide the public with access to justice.

\section{B. The Realities of the System}

Chief Justice Burger has asserted, in his now-famous lectures at Fordham University in 1973, that the criminal lawyer in America is more often inept in the courtroom than not. ${ }^{30}$ Judge Bazelon, who finds a constitutional basis for the requirement of adequate counsel, contends that most indigents in criminal cases are represented by "walking violations of the Sixth Amendment." ${ }_{1}$ Many judges have claimed that fewer than twenty-five per cent of the lawyers appearing before them are competent; at least one judge puts this figure as low as two per cent. ${ }^{32}$

There are several reasons for this widespread deficiency. One is the antiquated traditional notion that members of the bar are universally qualified to cope with the full range of legal issues. ${ }^{33}$ In fact, admission to the bar has little bearing on the quality of a trial advocate. Criminal law practice is both a specialty and an art. It requires an experienced and skilled advocate who is not only qualified in the courtroom, but versed as well in the workings of the criminal justice system-from the practices of private crime labs to the intricacies of plea bargaining. ${ }^{34}$

The shortage of competent attorneys is not generally felt in the large firms. An apprenticeship period is common practice in these establishments, during which the inexperienced lawyer assists more experienced associates in the preparation and trial of their cases, and, it is hoped, in the process, "learns the ropes." 35 Thus the well-to-do client of a large firm does not ordinarily suffer; it is the indigent who bears the brunt of a lack of formal apprenticeship programs. Many indigents consequentially are deprived of effective legal assistance. ${ }^{36}$

Another cause of inferior representation is found in the practices of the legal education system. Mr. Justice Robert Jackson stated the problem at the

29. A.B.A. Code of Professional Responsibility DR 6-101.

30. Wall Street Journal, Nov. 27, 1973, at 6, col. 3.

31. Bazelon, The Defectize Assistance of Counsel, 42 U. CInN. L. REv. 1, 2 (1973).

32. Tamm, Advocacy Can Be Taught-The N.I.T.A. Way, 59 A.B.A.J. 625 (1973).

33. Burger, supra note 1 , at 231.

34. See United States v. DeCoster, 487 F.2d 1197, 1203 (D.C. Cir. 1973).

35. Burger, Special Skills of Advocacy, 48 FLA. B.J. 154, 156 (1974).

36. Bazelon, supra note 31 , at 2 . 
Stanford Law School Dedication in July of 1950: "If the weakness of the apprentice system was to produce advocates without scholarship, the weakness of the law school system is to turn out scholars with no skill in advocacy." 37 The typical law school program does not emphasize instruction in courtroom skills. Legal education instead rests on the bedrock of the casebook system because of its efficiency in disseminating information to large numbers of students by small numbers of faculty members. ${ }^{38}$ Only recently have law schools begun to include clinical programs on trial advocacy. In addition, some state and federal courts have recently adopted rules which permit third-year law students to aid attorneys in trial work. In spite of this progress, the neophyte criminal trial lawyer all too often finds himself not merely unsure of what to do next in a courtroom, but unsure what to do first. ${ }^{39}$

A third cause of scarcity of efficient criminal trial lawyers is the near-crisis case load of the courts. In the past three decades, the volume of criminal cases has risen dramatically. Various factors such as the Criminal Justice Act, the Bail Reform Act, the extension of the new federal standards to state courts, rising population, and an increasing crime rate are responsible for the flood of cases. ${ }^{40}$ The resulting backlog compels courts to tolerate an excess of plea-bargaining which fosters defective legal assistance. Emphasis is on settling cases as quickly as possible to make room on the docket. ${ }^{41}$

\section{The Functions and Attributes of Competent Criminal Law Attorneys}

\section{The Criminal Law Attomey as Trial Aduocate}

By definition, a criminal lawyer must be a trial attorney. ${ }^{42}$ Professor James McElhaney lists five broad based common denominators that all competent trial lawyers should posses. First, a thorough, working knowledge of evidentiary law in the trial setting. Second, a knowledge of trial procedure from the motion practice and discovery devices to courtroom etiquette. Third, knowledge of the fundamental skills employed in direct and cross-examinations, opening statements, closing arguments and introduction of evidence. Fourth, the judgment to gain maximum benefit from all these skills. And fifthskilled advocacy. ${ }^{43}$

37. McElhaney, Trial Adtocacy as a Specialty, in Special Committee on Specialization, A.B.A., Legal Specialization 34, 37 (1976).

38. Id.

39. Bazelon, supra note 31 , at 13 .

40. Id. at 5 .

41. Id.

42. Douglass, The Prosecutor's Viewpoint, in Special Committee on Specialization, A.B.A., Legal Specialization 230 (1976).

43. McElhaney, The Trial Adrocacy Specialist, in Special Committee on Specialization, A.B.A., Legal Specialization 153, 155 (1976). 


\section{The Defense Counsel}

The defense counsel must be champion for his client. ${ }^{44}$ The defendant usually faces a hostile world, and his lawyer cannot be timorous in his defense. Defense counsel must vitiate prejudice as much as possible and place his client on equal footing with the State in the courtroom. He enables his client to communicate in a foreign environment, and he must establish a rapport with his client to initiate a free flow of information between them.

In United States \%. DeCoster, Judge Bazelon set forth his criteria for the competent defense attorney. ${ }^{45}$ First, in order to discuss various options and determine the best course of defense, he must confer with his client without delay and as often as necessary. Counsel should promptly advise his client of his rights and do everything possible to preserve them. The defense attorney should attempt to have his client released until his trial. Finally, counsel must investigate the available avenues of defense. Judge Bazelon concluded in DeCoster, that if the defendant can show a substantial violation of any of these duties, the burden shifts to the government to prove the lack of prejudice from such violation. The result can be a new trial for the defendant. ${ }^{46}$

\section{The Prosecutor}

While subject to the same standards as the competent defense attorney, ${ }^{47}$ the prosecutor is also in a unique position. The leading officer of law enforcement in the community, he is more often in the public eye than the defense attorney, more likely to be drawn into political controversy and thus more subject to the pressures of the complex system he represents. As the state's representative, he is vulnerable to public opinion in a way that the defense counsel is not. To be effective, the prosecutor must combine the abilities of an able trial attorney who has mastered the intricacies of the courtroom with the ability of a public relations official who can respond ably to public inquiry at a press conference. ${ }^{48}$ And, with the current case load back$\log$, the prosecutor must be expert in plea-bargaining. ${ }^{49}$

II

Specialization in Criminal law-A Remedy?

It is generally acknowledged that the public is not receiving adequate legal representation in the field of criminal law. Chief Justice Burger has observed that "our 'delivery' of justice, to borrow a term from experts in medical care,

\footnotetext{
44. A.B.A. Project on Standards for Criminal Justice, supra note 27, at 145-147.

45. United States v. DeCoster, 487 F.2d 1197 (D.C. Cir. 1973)

46. Id. at 1203,1204 .

47. A.B.A. Project on Standards for Criminal Justice, supra note 27 , at 19.

48. Id. at $19,20$.

49. Id. at 21 .
} 
is faltering and inadequate." ${ }^{50}$ Faced with this situation, the American Bar Association must find a mechanism to weed out most, if not all, of the incompetent criminal lawyers. The question is how to achieve this goal. Judge Bazelon stated in the Robert S. Marx lectures, delivered in 1972, that the "linchpin of any screening mechanism is certification." ${ }_{1}$ He contended that specialization through certification is the only practical and effective way to achieve and maintain high standards of quality in criminal attorneys. ${ }^{52} \mathrm{~A}$ program of specialization in criminal law should guarantee to the public that the attorneys involved in a criminal matter are qualified or at least experienced in that area.

\section{A. Tools for Certification}

If one accepts the premise that a certification program will improve the quality of criminal lawyers, then the corollary inquiry must be what evaluative tools should be used. Required courses in law school, continuing legal education, special oral and/or written examinations, practical experience, and peer evaluation are the methods being tried by the various pilot programs now projected and in operation.

\section{Law School Education}

There is considerable support among advocates of criminal law specialization for the training of specialists in law schools. ${ }^{53}$ Chief Justice Burger has remarked that if we abandon the tradition of giving students a three month vacation each year, basic legal education could be completed in two years. ${ }^{54}$ The Carrington Report concurs in finding that the skills of general law practice can be taught in two years without mentioning a deletion of summer vacations. ${ }^{55}$ If two years is sufficient for a basic legal education, then the third year of law school is largely wasted in non-directed study. Those who support the training of specialists in law school argue that this third year could be devoted to narrowing the scope of the students' education. In addition to substantive courses in criminal law, interested students could take clinical courses under the guidance of practitioners as well as professors. ${ }^{56}$ One major advantage to this approach is the elimination of recurring situations in which a fledgling attorney gains experience at his client's expense.

50. Burger, Has the Time Come?, 55 F.R.D. 119, 123 (1972).

51. Bazelon, supra note 31 , at 18 .

52. Id.

53. See Powers, The Role of Law Schools in the Training of Legal Specialists, 42 FLA. B.J. 1120 (1968); A.B.A. Section of Legal Education and Admissions to the Bar, The Role of Legal Education in the Preparation of the Legal Specialist 6-7 (Monograph 2, 1971); Burger, supra note 1, at 227.

54. Burger, supra note 1 , at 232

55. 1971 Ass'n Ам. L. Schools-Proceedings pt. 1, § 2, at 7-9 (1971).

56. Burger, supra note 1 , at 232. 
A second suggestion for utilizing the legal educational system to implement specialization is postgraduate training programs. ${ }^{57}$ However, there is concern that limited access to such programs would result in the formation of an elitist group. ${ }^{58}$ The existence of a small coterie of criminal law specialists will not achieve the primary designated goal of specialization: to provide the general public with access to competent criminal lawyers. ${ }^{59}$

A further problem in using either a J.D. program or a postgraduate program to create specialists, is the tension which will inevitably arise between what state bar associations or the ABA will accept as sufficient educational training and what law school faculties feel is feasible to include in their curricula. ${ }^{60}$

\section{Contiming Legal Education}

Continuing legal education (CLE) courses are primarily designed to aquaint an attorney with new developments in his field of practice. Because a CLE program is best suited to correcting deficiencies in a lawyers's education and practical experience, it has been suggested that CLE should have a limited role, if any, in the initial certification of a specialist. By contrast, CLE should figure prominantly in recertification programs, where emphasis is on keeping abreast of the latest developments in an area of law. ${ }^{61}$ A CLE course usually consists of a series of lectures given by a volunteer to a large number of attorneys. Frequently, no preparation is required of the participants and there is no examination, thus reducing the motivation to study. The participants' typical motives for attending vary from fulfilling law firm or state bar requirements to obtaining an excuse to 90 to the city where the program is being held. Despite these shortcomings, the value of CLE in maintaining the quality of criminal law attorneys should not be underestimated. In light of the changing dictates of the Supreme Court, an attorney must be knowledgeable in the latest case law if he is to perform competently.

57. Kornblum, The Lau School's Role in Post-J.D. Specialty Education, 5 J.L. REFORM 436, 443 (1972).

58. Friedman, The Impact of Specialization on Legal Education, in SPecial CommitTeE on Specialization, A.B.A.. Legal Specialization 81, 90 (1976).

59. Commitee on Specialization, Criminal Justice Section, ABa, Report of meeting held at Houston, Tex., July 9, 1976.

60. Cf. Beytagh, Prescribed Courses as Prerequisites for Taking Bar Examination: Indiana's Experiment in Controlling Legal Education, $26 \mathrm{~J}$. LEGAL ED. 449, 458-460 (1974). One possible escape from this tension is to have such skills as formal trial advocacy education conducted outside law school. In recent years this has become a significant trend, perhaps because of a general desire to avoid entanglements with existing law school curriculum. At present such institutions are not joined by any accrediting association since most programs-even those with excellent curricula and personnel-are still considered to be in the experimental and development stages. McElhaney, supra note 37 , at 44.

61. Friedman, supra note 58 , at 91 . 


\section{Experience}

Day-to-day experience in practice plays a vitally important function in serving to home and temper the raw skills of an attorney into those of a specialist. ${ }^{62}$ A variation on the plan to use the third year of law school to produce qualified criminal counsel is that of implementing a mandatory one year internship program. This year could be inserted following the completion of the two year general portion of the J.D. program and before the final year in school.63 An alternative to a mandatory clerkship while in school would be to require that a neophyte lawyer gain experience by serving as co-counsel on a number of criminal cases. ${ }^{64}$ Both of these proposals focus on methods by which a young lawyer can become a competent criminal lawyer through serving something akin to an apprenticeship. Yet another proposal would not require experience through apprenticeship for beginning lawyers but would require an attorney to have practiced for a specified number of years and to have been substantially involved in criminal law if he is to be certified as a criminal law specialist.

Different criteria have been given in various state plans as to what constitutes substantial involvement in a given area of law. Among these criteria are: a certain percentage of an attorney's working time spent in a given area; a certain number of cases in an area of the law; participation in educational programs in an area as a student or lecturer; authorship of a book or article in the field; or, any combination of the above. ${ }^{65}$

\section{Examinations}

Some believe that examinations would be helpful in any certification process although the type of exam to be administered and the ultimate weight to be given the scores are debated issues. ${ }^{66}$ Written exams may accurately reflect one's knowledge of the substantive law, but their limitations are obvious. A lawyer may be able to recognize a hearsay problem on a written exam, but in a courtroom situation with constant interchange between the participants he may not be able to do so.

The courtroom situation can more readily be simulated in an oral examination, yet with oral exams there is the problem of subjectivity. There is not always one correct answer to every question that arises in the course of a trial, and examiners may react differently to various answers to a given question.

62. See Burger, supra note 1, at 230; Bazelon, supra note 31 , at 19.

63. Sovern, et al, Training Tomorrow's Lauvers: A Response to the Chief Justice's Challenge, 11 Colum J.L. \& Soc. Problems 72, 76 (1974).

64. Bazelon, supra note 31 , at 19.

65. Cf. New Mexico Plan, supra note 18. Sep California Plan supra note 17 and the ABA Committee on Criminal Specialization.

66. McElhaney, supra note 37 , at 46 . 
Oral testing could become confused with a popularity contest. over the applicant. Advocates of oral examination nevertheless contend that despite the problem of subjectivity, certain fundamental skills can be tested by strictly controlled courtroom scenarios. ${ }^{67}$

\section{Peer Evaluation}

Peer evaluation is arguably a valuable tool in assessing an attorney's professional qualifications since attorney's peers have had the opportunity to witness his handling of actual cases. Here again, subjectivity is a problem. Due to the nature of criminal practice, a good defense attorney by his aggressive nature is bound to make enemies among prosecutors and judges. Even disregarding the problem of subjectivity, peer recommendations are hard to evaluate. Questions are usually presented under a format of point rating. The difficulty lies in contructing an overall framework into which to place the scores. The value placed on different criminal advocacy skills is by necessity arbitrary, and thus limited in usefulness. ${ }^{68}$

\section{B. Application of the Tools: Three Approaches to Criminal Law Specialization}

All the above tools are potentially valid techniques for evaluating criminal attorneys and establishing a system of specialization in criminal law. Various combinations of these components have resulted in three distinct approaches to specialization among the various state plans.

\section{The California Plan}

The California Plan was the first state plan to be approved and implemented. It was adopted by the California Supreme Court in February 1971, and it has been in operation on an experimental basis since 1973. The plan was developed for a bar consisting of approximately 40,000 members, most of whom practice law in the Los Angeles or San Francisco area. ${ }^{69}$ The program is governed by a nine-member Board of Specialization which in turn appoints advisory commissions for each designated specialty to establish and regulate standards in that area. At present, three areas of the law have been approved as specialties: criminal law, workmen's compensation, and taxation. $^{70}$

67. McElhaney, supra note 37 , at 46.

68. Derrick, Problems Encoumtered in Dezeloping Existing Standards, in Special. Committee on Specialization, A.B.A., Legal Specialization 196, 198 (1976).

69. R. Zehnle, Specialization in the Legal Profession 3 (1975).

70. Id. at 4 . 
The plan which California adopted is a certification type program.

A certification program will typically have detailed, extensive, and high qualifying standards for certification or recertification in any specialty. A rationale frequently given for adopting this kind of program is the responsibility of the state bar to insure the public that those attorneys who are designated specialists are indeed competent in their specialty. ${ }^{71}$

For the sake of clarity, the requirements of the California Plan will be compared with the general requirements listed in section $\mathrm{B}$ above, which are frequently proposed for any specialization plan.

\section{a. Legal education}

There is no requirement in California that certain designated courses must be taken in law school in order to become a criminal law specialist.

\section{b. Continuing Legal Education}

California requires Continuing Legal Education for both original certification and recertification. The number of hours of CLE necessary for original certification increased yearly from implementation until 1976. In 1974 an attorney was required to have attended twenty hours of CLE programs within the three years preceding his application; in 1975 thirty hours were required; and in 1976 forty-two hours were required. ${ }^{72}$ To be recertified, an attorney must have completed thirty-six hours of CLE within the five-year certification period. ${ }^{73}$ All classes attended to comply with the CLE requirement must be approved by the California Board of Legal Specialization. The educational program must provide advanced instructors in areas such as criminal trials, criminal procedure, evidence, constitutional law, and the operation of administrative adjuncts of the criminal law system such as public prosecution and defense offices, probation departments, law enforcement agencies, and correctional agencies and institutions. ${ }^{74}$

\section{c. Experience}

California requires that an attorney practice law for at least five years in California before being considered for certification as a criminal law specialist. $^{75}$ Moreover, he must have had substantial involvement in the criminal

71. Davidson, A Brief for the Florida Plan, 48 FLA. B.J. 184 (1974).

72, California Plan, Standards, \$ II.C.; California Plan, Rules and Regulations $\S 3(\mathrm{a})(1)$.

73. Caljfornia Plan, Rules and Regulations $\$ 3(a)(2)$.

74. California Plan, Standards \$II.C.

75. California Plan, Standard $\$$ il.A.

Practice of law is defined as full-time legal work done primarily for purposes of legal advice or representation. Service as a judge after admission to any state bar or that of the District of Columbia will count as practice of law. Corporate or government service will be counted as prac- 
law field. In order to satisfy this "substantial involvement requirement," an attorney inter alia must be the principal counsel of record in five jury trials where the offenses were felonies, in five additional jury trials regardless of the offenses, and in forty additional criminal matters. ${ }^{76}$ Further, the applicant must show that within three of the five years preceding this petition for certification, he spent a minimum of one-third of his time in the practice of criminal law in California. ${ }^{77}$

\section{d. Examinations}

The applicant must pass a written examination prior to certification. This examination tests the applicant's knowledge of substantive and procedural criminal law and related fields. ${ }^{78}$

e. Peer evaluation

California requires that the applicant submit the names of references to attest to his proficiency in criminal law. Four of these references must be lawyers who practice in the same geographic area as the applicant. One reference must be a judge before whom the applicant has tried a case. Three references must be California lawyers with whom the applicant has tried a case but who are not associates of the applicant. In addition the Criminal Law Advisory Commission will select at random four lawyers or judges who practice in the same area as the applicant to provide further evaluation. In order to be certified, the applicant must receive favorable recommendations from at least eight of these twelve individuals. ${ }^{79}$

During the initial years of the California Plan, an alternative method of certification was provided by use of the "grandfather" clause. In order to take advantage of grandfather certification an attorney had to apply within two years after implementation of the Plan. To qualify under this method, an

tice of law only if the work was legal in nature and primarily for purposes of legal advice to or representation of the corporation or government agency.

76. Additionally, California Plan, Standards $\S$ II.B requires that an applicant have done any two of the following:

(1) Five hearings in which oral testimony was taken in which decisions have been rendered, and three petitions on answering filed in extraordinary court proceedings in which decisions after hearing have been rendered in the following courts: United States Supreme Court, United States Court of Appeals, United States District Court, California Supreme Court, California Superior Court; or

(2) Three appeals in any of the above courts in which briefs were filed for the appellants and respondents; or

(3) Ten additional jury trials submitted to the jury for a decision regardless of the nature of the decision; or

(4) Three years in full time practice of criminal law in California.

77. California Plan, Standard $\$$ II.B.

78. Callifornia Plan, Standards $\$$ II.D.

79. California Plan, Standards $\S$ II.E. 
applicant had to have practiced law for at least ten years and to have been substantially involved in the criminal law field during that period. ${ }^{80}$ In February of 1976, in a meeting to evaluate its plan, the California Board recommended that the requirements under the grandfather provision be strengthened, including a requirement for special educational experience. ${ }^{81}$

After being designated a criminal law specialist, an attorney is able to advertise publicly, utilizing the phrase "Certified Specialist, Criminal LawCalifornia Board of Legal Specialization," in the yellow pages, in legal directories, and in law lists. ${ }^{82}$ The Board recommended at an evaluational meeting in February 1976 that the scope of such advertising should be widened to include professional cards and letterheads. ${ }^{83}$

The certification period is five years, after which an attorney must be recertified. There are two alternative methods by which an attorney can be recertified, the first method imposing requirements almost as extensive as those for original certification. The requirements under the first method of recertification are that an attorney must have been engaged in the practice of law in California for at least ten years prior to the date on which the certificate of specialization is due to expire, five of which shall have been during the current certification period; that he must show substantial involvement in the practice of criminal law during the current certification period (in the manner outlined above); and that he must show that he has completed thirty-six hours of CLE courses. ${ }^{84}$ The second alternative for recertification, if an applicant does not meet the requirements of the first method, is that he must successfully complete a written examination in order to demonstrate his continued special knowledge, proficiency and experience in the field of criminal law and related fields. ${ }^{85}$

Many proponents of the California Plan argue that its stringent requirements are necessary since the public will assume that once a lawyer is certified by the state bar as a specialist, that he is competent in his specialty. ${ }^{86}$ However, critics of the Plan contend that by establishing such unreasonably high standards for certification, the plan actually deters specialization. ${ }^{87}$ Critics of

\footnotetext{
80. R. ZEHNLE, supra note 69 , at 4 .

81. D. Fromson, supra note 2, at 20.

82. Pilot Program in Legal Specialization, $\$ 12($ b)(i), (ii), approved by the California Supreme Court, Feb. 10, 1971.

83. D. Fromson, supra note 2, at 22.

84. California Plan, Rules and Regulations $\S 3($ a) $(2)$; California Plan, Standards $\S$ III.A(1) and (2).

85. California Plan, Standards \$ III.B.

86. R. ZeHNLE, supra note 69 , at 5 .

87. Id.

In its first year in operation only 1,509 of the state's attorneys applied for specialization in any of the three specialties and 1,157 (77 percent) of these were "grandfathers," who by definition have already been specializing in one of the fields. Of the 1,229 who were certified, 1,013 (or 82.5 percent) were "grandfathers." It has been pointed out however that although the California
} 
the California Plan are not convinced that its extensive requirements actually insure competence. Among other arguments they cite the contention, already noted in this article, that a written examination is an ineffective test of a criminal lawyer's skill in courtroom advocacy. ${ }^{88}$

\section{The Other Extreme: New Mexico}

The New Mexico Plan, enacted to serve a bar of 1500 lawyers, was adopted on September 1, 1973, after being approved by the state's Supreme Court in July of that year. The plan is regulated by a nine-member specialization board. ${ }^{89}$

The New Mexico program does not include specific requirements for each individual area of the law, but rather sets forth general standards which apply to all fields that it designates as specialties, including criminal law. ${ }^{90}$ Unlike California's Plan, New Mexico's specialization program does not have stringent standards for certification as a specialist. In fact, its plan does not measure the competence of an applicant in any objective way.

The New Mexico Plan is basically one of self designation. The only criteria used to designate a specialist are an attorney's experience and involvement in a particular field of law. In order for an attorney to become a specialist, he must certify, and be ready to substantiate, that he has spent at least sixty per cent of his working time in his specialized area for each of the five years prior to his application. ${ }^{91}$ There is no formal recertification procedure. In order to maintain his designation, the specialist, must attest and be able to prove at any time that he has continued to spend sixty per cent of his working time in his designated field. ${ }^{92}$

Once an attorney is certified a specialist he may then list himself as "Specializing in criminal law" in the yellow pages, under his alphabetical listing on bar lists, and on professional cards and letterheads. ${ }^{93}$

\footnotetext{
Bar has over 50,000 members, not all were eligible for certification-only those in the three fields of tax, criminal law, and workmen's compensation. Of those that were eligible, two-thirds applied and half of these were certified. Standing Committee on Specialization, ABA, Interim RePORT: Discussion Draft (1976).

88. Pickering, Why I favor the New Mexico Plan, 48 FLA. B.J. 180 (1974).

89. R. ZEHNLE, supra note 69 , at 7 .

90. Those specialties thus far designated are:

Admiralty, Antitrust, Appellate Practice, Arbitration, Banking, Bankruptcy, Civil Rights, Collections, Condemnations-Eminent Domain, Consumer Protection, Corporations, Creditors Rights, Criminal Law, Domestic Relations, Estate Planning (complex wills-trusts), General Practice, Government Contracts, Indian, International, Labor, Legal Research for Attorneys, Military, Natural Resources, Negligence, Oil and Gas Mining, Patent, Copyrights and Trademarks, Personal Injuries and Property Damage, Probate and Wills, Product Liability, Real Estate, Securities, Taxation, Transportation, Trials, Water, Welfare and Poverty, Workmen's Compensation.

New Mexico Plan, § IV.

91. New Mexico Plan, $\$$ I(1)

92. New Mexico Plan, \& I(4).

93. New Mexico Plan, § I(3).
} 
The New Mexico Plan also provides that an attorney who is not a certified specialist may notify the public that his practice is primarily limited to three areas of the law which have been designated as specialties. ${ }^{94}$ This permits young lawyers who have not practiced the requisite five years to limit their practice and move toward establishing themselves as specialists in one field. These attorneys will not be economically disadvantaged in the interim because they are permitted to advertise the fact that they have limited their practice in the same media as the certified specialists. ${ }^{95}$

Defenders of the New Mexico Plan assert that it is not really a specialist plan; It is rather an identification plan whose primary goal is the dissemination of information that will aid laymen in choosing an experienced attorney. ${ }^{96}$ The defenders of the New Mexico plan also contend that the plan is much less expensive, complex and time-consuming to operate than the California Plan. ${ }^{97}$ Moreover, they point to its enthusiastic reception by members of the New Mexico Bar. ${ }^{98}$ One prominent adherent, Mr. Leonard Pickering, questions the efficacy of the rigorous standards utilized in California to achieve the goal of creating competent lawyers. He asserts that "New Mexico's Plan is based on one simple but correct fact-that the more time an attorney spends in his area of specialty, the more proficient he becomes in that area."99

Critics of the New Mexico Plan claim that its standards for certification are too lenient and that the public will be misled by the designation of an attorney as a specialist. However, in order to reduce the chance of misunderstanding by the public, the New Mexico Bar Association publicly disclaims any attempt by the plan to measure competence. For example, it has placed an explanatory notice in the yellow pages to the effect that designation as a specialist denotes only experience in the particular area of the law, and not competence or expertise. ${ }^{100}$ Nonetheless, many critics continue to assert that

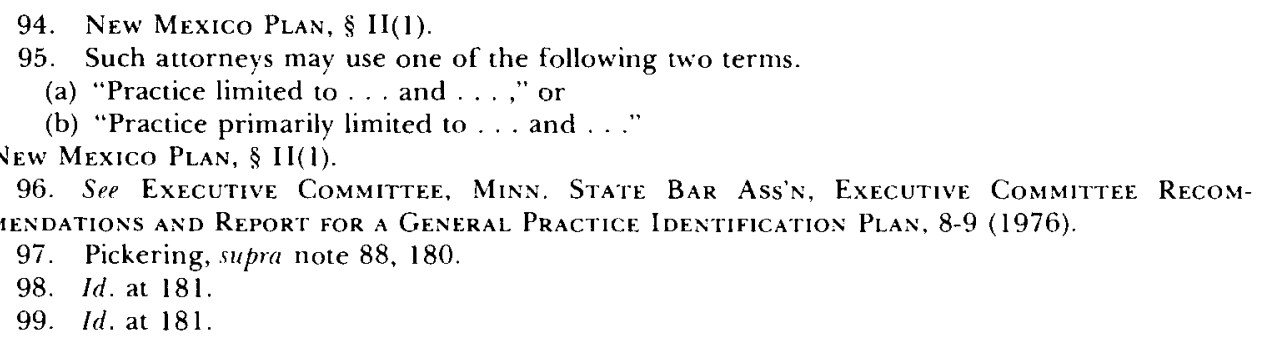

100. This explanation reads as follows:

\section{NOTICE}

For the general information of the public

Attorneys who have devoted $60 \%$ or more of their practice time to a certain specified and specialized area of the law for at least each of the immediate past 5 years and who continue to devote at least $60 \%$ of their practice time to such area of the law are permitted, if they so desire, to state that they "specialize" in such particular branch of law.

Such a listing means only that the attorney has had at least the required amount of experience in his specialty. It DOES NOT MEAN that anyone or any agency or Board 
despite such announcements ${ }^{101}$ the public will be misled by the listings. Skeptics also point to the fact that the Plan does not obligate an attorney to improve himself or keep up with current trends in his specialty. ${ }^{102}$

Thus, New Mexico's plan represents the order end of the spectrum from that of California. It provides easy access to certification by requiring only that an attorney attest to spending most of his working hours in his specialty. The cost of the plan is minimal and many attorneys have become specialists. Unlike California's goal of insuring that an attorney designated as a specialist has special competence, New Mexico's goal is simply to disseminate what it believes to be helpful and important information to the public.

\section{The Middle of the Road-The ABA Committee on Specialization of the Criminal Justice Section}

The ABA Committee on Specialization of the Criminal Justice Section apparently had reservations about both the California and New Mexico approaches to criminal specialization. ${ }^{103}$ The Committee was formed in 1974 for the purpose of preparing national standards to be recommended to state bar organizations for certifying lawyers as specialists in criminal justice. ${ }^{104}$ It focused on the acute need of the middle class to identify and to have access to lawyers who are competent in criminal law. ${ }^{105}$ Although the Committee did not lean toward adopting New Mexico's self-identification plan, it was equally opposed to following California's certification Plan. It felt that the California

has certified that such attorney is an "expert" in such field of law. Neither does it mean that such attorney is necessarily any more expert or competent than any other attorney. Attorneys may also list themselves as "limiting" or "primarily limiting" their practice to particular branches of the law.

"Practice limited" means that such attorneys do not take or handle any legal matters except in the fields of law specified.

"Practice primarily limited" means such attorneys are primarily interested in handling cases in the referred-to fields of law, but that they also handle other types of legal matters.

\section{ALL POTENTIAL CLIENTS ARE URGED TO MAKE THEIR OWN INDEPENDENT INVESTIGATION AND EVALUATION OF ANY} ATTORNEY BEING CONSIDERED.

This notice published by the State Bar of New Mexico, Tel. 842-30631117 Stanford, NE, Albuquerque, New Mexico 87131

Pickering. The New Mexico Plan for Recognition of Specialization, 5 ALI-ABA CLE Rev., Jan. 25, 1974 , at 5

101. R. ZEHNE, supra note 69 , at 8 .

102. Id. At this writing, Mr. Leonard Pickering has stated that there is considerable interest and support for including a CLE program in New Mexico's specialization plan. No action has yet been taken. Telephone conversation with Mr. Pickering, Chairman, Specialization Board of the Supreme Court of New Mexico, January 1977.

103. Committee on Specialization, Criminal Justice Section, ABa, supra note 59.

104. $I d$. at 1 . The first meeting of the committee took place in November, 1975 in Jacksonville, Florida.

105. Id. at 2. 
Plan created a small coterie of high-priced criminal lawyers by promulgating nearly unattainable standards. ${ }^{106}$ The Committee believed that the rigidity of the California Plan went further than was necessary to accomplish the goal of assuring the public that it was obtaining competent criminal defense. It contended that many lawyers are qualified to render effective criminal law representation despite their broad areas of practice. Accordingly, it decided that an attorney need not devote a substantial part of his time to criminal law to be recognized as a competent criminal law attorney. In establishing its standards, the Committee decided not to use the term "specialist" since this implies a higher degree of skill than is necessary to provide competent criminal law representation. Instead the Committee agreed to use the term "qualified." 107

With the foregoing approach in mind, the Committee recommended the following guidelines for certifying that an attorney is "qualified" to be a counsel in a criminal case. Again, for the sake of comparison the committee's standards are categorized.

\section{a. Legal education}

The Committee did not require any specific course curriculum in law school as a prerequisite to certification in the criminal law area. ${ }^{108}$

b. Continuing Legal Education

Utilization of continuing legal education programs was recommended in the recertification process, but not in the initial certification process. ${ }^{109}$

\section{c. Experience}

The Committee eschewed the requirement that an attorney have practiced law for a certain number of years. It reasoned that the number of years an attorney has practiced does not necessarily correlate with his degree of competence. However, the Committee did stipulate that the applicant must have been substantially involved in criminal law matters in the five years prior to his petition for certification. ${ }^{110}$ It was suggested that he be required to have handled fifty criminal law matters within that five year period. Out of these fifty matters, ten should have been felony trials and at least five should have

106. Id. at 2. The committee felt that any "attempt to set higher and more standards will create an aristocracy of lawyers whose credentials will be difficult to define but who will likely primarily serve those clients who can afford to pay more for superior expertise.

107. $I d$.

108. Id. at 3,4 .

109. Id. at 4 .

110. Id. at 3, "Criminal matters" were defined very broadly and include "advice," "legal representation," and "services"-in fact, almost any matter that affects a defendant in a criminal way." 
been submitted to a jury for its determination of guilt or innocence. ${ }^{11}$ The Committee further suggested that one of the criminal matters be an appeal. ${ }^{112}$ A requirement of familiarity and competence in pre-trial procedures was also suggested as an optional standard. ${ }^{113}$

\section{d. Examinations}

The committee recommended that a written examination be required only in the recertification procedure. The examination should cover significant changes that have occurred within the preceding three years and should also deal with substantive fundamentals of criminal law and ethics. However, the exam should not be as difficult as a bar examination. The Committee felt that the exam should measure levels of minimum expertise necessary for competence, but should not be considered proof of superior quality. ${ }^{114}$

\section{e. Peer Evaluations}

The Committee made no recommendations concerning peer evaluations either in the certification or recertification process.

These recommendations are broad proposals that have not been fully developed by the Committee nor adopted by the American Bar Association. They represent the philosophical approach of the Committee toward criminal specialization. The Committee wants only to assure the public that an attorney certified by his state bar in criminal law is qualified, not necessarily that he is an expert. In the opinion of the Committee, this approach is sufficient to attain the goals of specialization in any area of the law. To demand that an attorney not only be qualified, but also that he limit the majority of his practice to criminal law, does not serve the public any more adequately, and may even discourage attorneys from seeking certification. ${ }^{15}$

\section{The Plans of Other States}

Twenty-one other states have either adopted or proposed specialization plans. These are listed below, categorized according to whether they follow the California, New Mexico or a hybrid approach.

These state plans share several common features. There is no mandatory specialization provision in any of the pilot programs; all of the plans are vol-

111. Id., "Trial" was defined as "a proceeding which results in jeopardy attaching other than by a guilty plea."

112. Id. It was pointed out that many prosecutors and public defenders never appeal cases and could therefore not qualify. The Committee then recommended that this requirement be waived if the person asking to be certified as "qualified" could show special circumstances which prevented him from appealing cases (as with prosecutors who have a limited right of appeal or public defenders whose offices have separate appellate departments)

113. Id.

$114 . \quad I d$. at 4 .

115. Id. at 2,3 : 
untary. Each of the programs states that an attorney is not prohibited from practicing in any field by the fact that he is not a specialist in that field. And there is a stipulation in every plan that an attorney who is a specialist is not prohibited from practicing in an area where he is not specialized. The plans all provide for revocation of specialization status by their respective bar associations where warranted and include a right to an appeal by the attorney. ${ }^{116}$

\section{Plans Similar to California's Certification Program}

Seven state specialization plans have followed California's approach: Alaska, Colorado, Indiana, New Jersey, South Carolina, Texas, and Washingtion. ${ }^{117}$ Texas' specialization pilot program is already operative. ${ }^{118}$ Washington's plan has been adopted by the Board of Governors, and approved by the state Supreme Court, and the Legal Specialization Board is presently formulating plans for its implementation. ${ }^{19}$ The pilot programs of Colorado, New Jersey and South Carolina have been approved by their respective bar

116. R. ZEHNLE, supra note 69 , at 3 .

117. See generally: Specialization Committee, Al.aska Bar Ass'n., Legal. Specialization Program (1976) [hereinafter cited as Alaska Plan]: Specialization Committee, Colorado Bar Ass'n, A Plan to Certify Specialists in Law (1972) [hereinafter cited as Colorado Plan]; Specialization Committer, Indiana State Bar Ass'n., Rules for Certification for Attorneys (1975) [hereinafter cited as Indiana Plan]; Specialization Committee, New Jersey State Bar Ass'n, Pilot Program for Voluntary Specialization in New Jersey (1973) [hereinafter cited as New Jersey Plan]; Specialization Committee, South Carolina Bar, Pilot Program in Legal Specialization (1976) [hereinafter cited as South Carolina Plan]; Special Committee on advisability of Specialization Recognition, State Bar of Texas, Texas Plan for Recognition and Regulation of Specialization in the Law (1974) and Texas Board of Legal Specialization, State Bar of Texas. Standardos for Certification of a Criminal. Law Specialist (1976), both Texas documents on file with Texas Board of Legal Specialization, Austin [hereinafter cited as Texas Plan and Texas Criminal. Law Standards respectively]; Legal Speclalization Board, Washington State Bar Ass'n, Plan for Certification of Specialists in the State of Washington (1974) and legal Specialization Board, Washington State Bar Ass'n, Standards for Certification in the Criminal. Law Specialty (1975) [hereinafter cited as Washington Plan and Washington Criminal Law Standakds respectively]; all the above are on file with authors except where otherwise indicated. Kentucky's Board of Governors is presently considering a general proposal which upon implementation could be similar to the certification approach. The standards for certification in each specialty "shall be sufficient to provide for objective evaluation of the qualifications of any applicant for certification, including experience, special training and substantial involvement in such specialty field." Kentucky's program also calls for a second tier of recognition, with a lower threshold of qualification, which will enable attorneys to advertise the fact that they limit their practice to certain areas. See generally Specialization Committee, Kentucky Bar Ass'n, Proposed Specialization Rules (1976), on file with authors.

118. Standing Committee on Specialization, ABA, Sunvey of Legal Specialization 19 (1976).

119. Id. at 21. The Board of Governors of the Washington State Bar recently voted down the implementation of what would have been the nation's first two tiered specialization program. This program, similar to the one proposed in Florida, would graft the self-designation plan of New Mexico onto the certification plan of California. An attorney could self-designate his areas of interest, but would have to pass rigid, examinations to be certified a specialist. 
associations and respective state supreme courts. ${ }^{120}$ The Alaska plan and the Indiana Plan have yet to be ratified by their state bar associations. ${ }^{121}$

Each of these seven state plans have set forth the minimum, general requisites for certification in any specialty area. ${ }^{122}$ Texas and Washington have in addition adopted specific guidelines for certification of criminal law specialists.

Thus, in dealing with the Washington Plan and Texas Plan for specialization in criminal law, this article will be drawing from specific requirements for criminal law specialists which were drawn up with the assistance of criminal law advisory committees in each state. In contrast, in dealing with the plans of Alaska, Colorado, Indiana, New Jersey, and South Carolina, this article will refer to general minimum requirements set by the respective state boards which apply to all specialties, including criminal law.

\section{a. The Governing Body}

Each of the seven pilot programs is regulated and controlled by a state board of specialization. The basic duty of these governing boards is the efficient administration of the pilot programs. ${ }^{123}$ The state plans also provide for satellite advisory committees to assist the board in formulating standards for the individual specialties and in regulating the program. ${ }^{124}$ The necessity and inevitability of expansion of the specialization programs to include additional specialty areas is recognized by the seven pilot plans. There is a provision in each program which enables the board to enlarge the program when desirable and feasible. ${ }^{125}$

\section{b. Requirements for Certification}

1) Residency requirements: Alaska, Colorado, Indiana, South Carolina, Texas, and Washington assert that an applicant must be a member in good standing of the state bar. ${ }^{126}$ New Jersey's plan has no such stipulation. Alaska,

\footnotetext{
120. Id. at $7,15,17$.
}

121. Id. at 5 and 9 .

122. Indiana and Colorado have not yet designated criminal law a recognized specialty in their pilot programs. However, in view of the popularity of criminal law as a fertile testing ground for pilot programs, it is highly probable that Colorado and Indiana will designate it as a specialty area at some point in the future.

123. Alaska Plan, articles I, II; Colorado Plan, rule 2; Indiana Plan, rules I, 2; New Jersey Plan, rules 1, 2; South Carolina Plan, rules 1, 2; Texas Plan, rules II, III; Washincton Plan, rules $1,2$.

124. Alaska Plan, art. 3; Colorado Plan rule 4; Indiana Plan rule 4; New Jersey Plan rule 4; South Carolina Plan rule 4; Texas Plan rule V; Washington Plan rule 4.

125. Alaska Plan art. V; Colorado Plan rule 10; Indiana Plan rule 2; New Jersey Plan rule 8; South Carolina Plan rule 10; Texas Plan rule XII; Washington Plan rule 3.

126. Alaska Plan art. IV; Colorado Plan rule 5; Indiana Plan rule 6; South Carolina Plan rule 5(a); Texas Plan rule VI; Washington Criminal Law Standards rule V(A)(1). 
South Carolina, Texas, and Washington also require specifically that a candidate must practice law and maintain an office within the state. ${ }^{127}$

2) The grandfather provision: Alaska, Colorado, Indiana, New Jersey, and Washington have two alternate methods of certification-one being the grandfather provision. ${ }^{128}$ Texas has limited the use of the grandfather method to the Labor Law field, ${ }^{129}$ and South Carolina permits no grandfather certification at all.

There is a uniform requirement in Alaska, Colorado, Indiana, New Jersey, and Washington that an application for grandfather certification must be submitted within two years of the date that the particular area of law was designated a specialty. ${ }^{130}$ Alaska requests that its grandfather applicants have practiced law on a full-time basis for a minimum of ten years. Indiana requires that the applicant have been engaged in the full time practice of law for seven of the last ten years. ${ }^{131}$ Colorado and Washington stipulate that in order to qualify for grandfather certification, an applicant must have practiced law for ten years or have experience in the law that their respective state boards deem to be equivalent. Colorado's plan states, additionally, that the requisite ten years must be those immediately preceding the application. On the other hand, in the Washington Plan, a candidate must have practiced law for ten years (or have equivalent experience) as of the date of the establishment of the Criminal Law Certification Panel. ${ }^{132}$ New Jersey is a bit more lenient, requiring that a grandfather candidate have practiced law for a minimum of five years, and adding no qualifying corrollaries. ${ }^{133}$

The pilot programs of New Jersey and Washington state that a grandfather candidate must be substantially involved in his specialty for a reasonable period before his petition is presented. ${ }^{134}$ New Jersey requires that an applicant show substantial involvement in his specialty within the three years immediately preceding his application. That state's plan does not define the term "substantial involvement" but implies that it should reflect competence through actual performance in the specialty area. ${ }^{135}$ Alaska and Indiana both require a grandfather applicant to be substantially involved in his specialty area for a three to five year period immediately preceding the application.

127. Alaska Plan art. IV; South Carolina Plan rule 5(b); Texas Pian rule VI; Washington Criminal Law Standards V(A)(2).

128. Alaska Plan art. IV(c); Colorado Plan rule 5(a); Indiana Plan rule 6(2); New Jersey Plan rule 5(a); Washington Criminal Law Standards rule V1.

129. Standing Committee on Specialization, ABA, supra note 118 , al 19.

130. Alaska Plan art. IV; Colorado Plan rule 5(a)(iv); Indiana Plan rule 6(2); New Jersey Plan rule 5(a)(iii); Washington Criminal Law Standardos rule VI(A).

131. Alaska Plan art. IV(c)(1): Indiana Plan rule 6(2)(a).

132. Colorado Plan rule 5(a)(i); Washington Criminal law Standards rule Vi(B).

133. New Jersey Plan rule 5(a)(i).

134. New Jersey Plan rule 5(a)(ii); Washington Criminal Law Standards rule Vi(C),

135. New Jersey Pl.An rule 5(a)(ii). 
Neither state attempts to define substantial involvement (in Alaska's case, "significant" involvement). ${ }^{136}$

Colorado's plan states that an applicant must have been "substantially involved" in his specialty for five years or a reasonable time, but in no case less than three years, immediately preceding his application. In setting forth the requirement of substantial involvement for grandfather candidates, Colorado's requirement of substantial involvement for grandfather candidates, Colorado's plan suggests several alternative criteria including: (1) time spent working in the specialty; (2) the number of cases handled in the specialty; (3) time spent teaching courses related to the specialty; or (4) a combination of these factors. ${ }^{137}$

Washington's pilot program states that a candidate must show substantial involvement in the criminal law field within the five years prior to his application. The Washington Criminal Law Section has specified the means to satisfy the "substantial involvement" requirement. First, a grandfather candidate must attest that within the requisite five-year period, he has spent at least fifteen per cent of his time each year working on criminal law matters. In addition, he must supply the Board of Legal Specialization with either (1) a computation of time based on a list of criminal law matters handled and an estimate of time spent on each matter or (2) a list of a specified number of felony trials, appeals, and other criminal matters. ${ }^{138}$

136. Alaska Plan art. IV(c)(2); Indiana Plan rule 6(2)(b).

137. Colorado Plan rules 5(a)(ii), 15(a). Colorado's plan associates substantial involvement with actual performance in a specialty field. The Bar recognizes that merely limiting an attorney's practice to an area does not indicate competence in that area. But the most objective standard possible must be used in evaluating specialist candidates. The specific requirements for certification must be defined by the Council with advice from the appropriate advisory commission. See Colorado Plan rules 4, 5. These standards for no event should be so restrictive as to unduly deter specialization or so lax as to make the certificate of specialization worthless.

138. Washington Criminal Law Standards rule VI(c).

If the grandfather candidate chooses alternate (1), he must satisfy the requirements of rule $V(B)(2)(a)$. He shall provide the certification board with an estimate of the total time he spent practicing law during the required five-year period. In addition, the applicant will provide the Panel with a list of the court of filing, cause title. cause number, type of case, charge, type of disposition, and result obtained. He shall specify an estimate of the time spent on each case and the basis for that estimate. The Panel, at its own discretion, may inquire further of the applicant with respect to any such proffered information. Listed cases may include felonies, misdemeanors, appeals, juvenile proceedings, civil involuntary mental health commitment proceedings, parole board proceedings, probation revocations, extraordinary writs, or other matters within the specialty, provided that felonies, misdemeanors, juvenile proceedings and appeals account for at least 80 percent of the listed time spent. The applicant must, in addition, list two felony jury cases tried by him during this period.

If the candidate for grandfather certification chooses alternate (2), then he must provide the Panei with proof that he has satisfied all of the following during the five-year period:

(1) fourteen felony trials, at least seven of which must have been before a jury;

(2) three appeals or extraordinary writs carried through to oral argument on the merits, or in the alternative, an additional six felony trials;

(3) one hundred matters within the scope of the specialty, with not less than ten or more than thirty of those being concluded in a given year. 
In addition, Washington's plan mandates that a grandfather candidate pass an oral examination and an abbreviated written exam. ${ }^{139}$ Both the programs of Alaska and Colorado require an oral examination. ${ }^{140}$ Neither Indiana nor New Jersey requires a grandfather applicant to take an examination of any kind. Indiana, however, does request that an attorney demonstrate "sufficient knowledge, proficiency and experience" as is necessary to justify certification. ${ }^{141}$

3) An alternate method of certification: There is another method of qualifying as a specialist besides grandfather certification. In programs, on the order of California's, this alternate method is characterized by the achievement of high standards before certification. In any explanatory material the emphasis is usually placed on the quality, not quantity, of the productspecialist attorneys. ${ }^{142}$

A fundamental requirement in all certification plans is that the candidate has to be engaged in the practice of law for a requisite number of years. Alaska, Colorado, Indiana, South Carolina, Texas, and Washington stipulate that a candidate must have practiced law for a minimum of five years. ${ }^{143} \mathrm{New}$ Jersey's requirement is three years. ${ }^{144}$

The plans of Colorado, South Carolina, Texas, and Washington also provide for a waiver of the requirement of five years of actual law practice if the applicant has had equivalent experience, as determined by their specialization boards. ${ }^{145}$ Of those four states, Washington most precisely defines the phrase "equivalent experience" to include: (1) full-time teaching of subjects within the specialty; (2) full-time clerkship for a justice of a state or federal appellate court with substantial involvement in criminal law; (3) experience as a court commissioner or a hearing examiner with substantial involvement in criminal law; (4) experience as a judge of a court with substantial involvement in criminal law and (5) other types of experience as may be approved by the Certification Board. ${ }^{146}$

Colorado, unlike Washington, does not define "equivalent experience" but rather provides that any experience which the Council determines is equiva-

139. Washington Criminal. Law Standards rule (VI(D).

140. Alaska Plan art. IV(b)(5); Colorado Plan rule 5(a)(iii).

141. Indiana Plan rule 6(2)(b).

142. Cf. Davidson, supra note 71 , at 184

143. Alaska Plan art. IV(b)(1); Colorado Plan rule 5(b)(i); Indiana Plan rule 6(1)(a); South Carolina Plan rule 5(c); Texas Criminal law Standards rule II(A); Washington Criminal law Standards rule V(B)(1)(a).

144. New Jersey Plan rule 5(b)(i).

145. Colorado Plan rule 5(b)(i); South Carolina Plan rule 5(c); Texas Criminal. Law Standards rule II(A); Washington Criminal Law Standards rule $V(B)(1)(b)$.

146. Washington Criminal Law Standards rule $V(B)(1)(b)$. The substantial involvement requirement that is a prerequisite to the acceptance of any substitute form of legal experience is defined supra note 138. Experience as a full-time clerk for a state or appellate court shall not supplant more than one year of actual law practice. 
lent to actual law practice will be acceptable to fulfill all or part of the fiveyear requirement. ${ }^{147}$ South Carolina's pilot program stipulates that if an applicant who has not been practicing law for five years has had specialized postgraduate education or concentrated experience within the specialty which is equivalent to or greater than the experience which would have been gained after five years of practice, then he will be deemed to have satisfied the requirement. ${ }^{148}$ The state of Texas defines "practice of law" to include: (1) experience as a judge in any court of record; or (2) corporate or government service, if the work done was primarily related to criminal law.149

Six states-Alaska, Colorado, Indiana, South Carolina, Texas, and Washington-have required that in order to obtain certification, an applicant must have been substantially involved in his specialty for a certain period of time prior to his application. A "substantial involvement" requirement has already been discussed in connection with grandfather certification in several states and this should not be confused with the discussion of the "substantial involvement" requirement in the alternative method of certification which follows.

The inchoate plans of Alaska and Indiana do not define the extent of substantial or significant involvement. The state plans of Colorado and South Carolina have identical requirements concerning "substantial involvement." A candidate for certification must fulfill this requirement during the three to five-year period preceding his application. Both plans link substantial involvement to actual performance in the specialty, and both plans suggest various criteria for evaluation. These criteria are: (1) time spent doing work in the specialty; (2) number of cases handled within the specialty; (3) time spent teaching subjects within the specialty; or (4) any combination of these factors. ${ }^{150}$ Note that these are the same criteria in Colorado for the "substantial involvement" requirement for grandfather certification.

In the Texas pilot program in order to demonstrate substantial involvement in the criminal law area, the candidate must: (1) show that within the previous two years he has devoted a minimum of twenty-five per cent of his time to practicing criminal law in the state of Texas; and (2) provide information to the Bar concerning cases handled within the scope of the criminal law specialty during the previous three years. ${ }^{151}$

Washington's "substantial involvement" requirement for the alternative method of certification is somewhat different from the requirement for grandfather certification. The candidate must demonstrate his substantial involvement in the criminal law field for the four-year period immediately pre-

147. Colorado Plan rule 5(b)(i)

148. South Carolina Plan rule 5(c).

149. Texas Criminal. Law Standardos rule II(A).

150. Colorado Plan rule 15(a); South Carolina Plan rule 5(d).

151. Texas Criminal Law Standards rule II(B). 
ceding his application. At least two of those years must have been in a Washington law practice. At the outset, the applicant must attest and be able to prove that he has spent not less than fifteen per cent of his working time during those four years on matters within the criminal law specialty. The applicant must further show substantial involvement in the criminal law field by either of two methods: percentage of time spent working on criminal law matters; or number of cases handled in the criminal law area. ${ }^{152}$

Five states-Alaska, Colorado, Indiana, South Carolina, and Texasrequire that an applicant show special educational experience within the specialty in order to be certified. ${ }^{153}$ Alaska and Indiana have not elaborated on this requirement. Colorado defines special educational experience to include: (1) CLE programs; (2) law school postgraduate work; (3) lecturing in symposia; (4) attendance at symposia; (5) rigorous self-study programs; and (6) apprenticeship in a specialty. ${ }^{154}$ South Carolina's plan states that to fulfill the educational requirement for certification, an applicant must complete successfully a course of instruction approved by the board and administered by the Bar of South Carolina or the University of South Carolina School of Law. ${ }^{155}$ The operative Specialization Plan in Texas states that an applicant must demonstrate to the board satisfactory educational experience within the criminal law area during the three years immediately preceding his petition. This requirement can be satisfied by attendance at and completion of programs of study for criminal law specialists approved by the board or by a showing of involvement in other activities of equivalent educational value. ${ }^{156}$

152. Washington Criminal Law Standards rule $V(B)(2)$.

The percentage-of-time method has the same requirements as those found in the provisions for grandfather certification set forth in footnote 138 supra.

The number-of-cases method has requirements somewhat different from those of the grandfather method of certification. The applicant must state information to show that he has been the principal counsel of record in all of the following:

(1) during the past three years, not less than eight felony trials, of which four were jury trials;

(2) during the same three years, not less than two appeals on extraordinary court proceedings to the Court of Appeals of the state of Washington, Washington State Supreme Court, United States Court of Appeals, or the United States Supreme Court, both of which shall be carried through to completion on the merits. In lieu of this requirement, the applicant can cite four additional felony trials;

(3) during the same three-year period, not less than sixty additional matters within the scope of the specialty, with not less than ten or more than twenty-five of such matters to have been concluded in each of the twelve month periods.

153. Alaska Plan art. IV(b)(3); Colorado Plan rule 5(b)(iii); Indiana Plan rule 6(1)(c); South Carolina Plan rule 5(d)(2); Texas Criminal law Standards rule II(C).

154. Colorado Plan rule 15(b). The requirements of special educational experience must be more specifically defined for each specialty field by the Council with the advice of the appropriate Advisory Commission.

155. South Carolina Plan rule 5(d)(2).

156. Texas Criminal Law Standards rule $\mathrm{I}(\mathrm{C})$. These other activities are similar to those suggested in the Colorado Plan, and include:

(1) teaching a course in criminal law;

(2) completion of a course on criminal law; 
All seven states require the passage of some examination in order for a candidate to achieve certification. Alaska, Colorado, Indiana, and Washington compel applicants to take both a written and an oral examination. ${ }^{157}$ New Jersey and Texas require a written examination. ${ }^{158}$ And South Carolina's pilot program stipulates that an applicant must pass an examination consisting of written and/or oral sections. ${ }^{159}$

The operative pilot program in Texas has some additional requirements for certification in the criminal law area. The candidate must furnish satisfactory evidence of his good character. This includes statements as to whether or not: (1) he has ever been subject to an investigation or other disciplinary measures by any segment of the Bar; (2) he has ever been convicted, given probation, or fined for a serious crime; and (3) he has ever been found by any court to have rendered inadequate representation in a criminal law case. In addition, like California's Plan, an applicant under the Texas pilot program must submit references to attest to his competence in the practice of criminal law. These recommendations must come from both judges and other attorneys. Moreover, the Texas Board of Legal Specialization may, on its own initiative, request information from other sources concerning the applicant's performance in the criminal law field. The applicant must also furnish a list of the judges before whom he has appeared on matters within the specialty during the past two years. ${ }^{160}$

c. Recertification.

Alaska, Colorado, Indiana, South Carolina, Texas, and Washington have certification periods of five years. ${ }^{161}$ The generalized pilot program of New Jersey makes no provision for recertification. The requirements for recertification in those six states are basically the same. Colorado, Texas, and Washington mandate a showing of continued substantial involvement and special educational experience within the specialty during the certification period. Alaska, Indiana and South Carolina request either a showing of sub-

(3) participation as a panelist or speaker in a symposium or similar program in criminal law;

(4) attendance at a lecture series or similar program concerning criminal law sponsored by a qualified educational institution or bar group;

(5) authorship of a book or article on criminal law, published in a professional publication or journal;

(6) active participation in the work of a professional committee dealing with a specific problem in criminal law; or

(7) such other educational experience as the Board shall approve.

157. Alaska Plan, art IV(b)(4)(5); Colorado Plan rule 5(b)(iv), (v); Indiana Plan rule 6(1)(d), (e), Washington Criminal Law Standards, rule V(b)(3).

158. New Jersey Plan rule 5(b)(ii); Texas Criminal Law Standardos rule 111

159. South Carolina Plan rule $5(\mathrm{~d})(3)$.

160. Texas Criminal Law Standards rules $\mathrm{I}(\mathrm{H}),(\mathrm{I}),(\mathrm{J}),(\mathrm{K}),(\mathrm{L})$.

161. Alaska Plan art VI(a); Colorado Plan, rule 6(a); Indiana Plan rule 12(1); South Carolina Plan rule 6; Texas Plan rule Vil; Washington Criminal Law Standards rule VII(a). 
stantial involvement, continuing educational experience, or the passage of an oral and/or written examination. ${ }^{162}$

\section{d. Advertising}

A key provision in any specialization program is the one which deals with the right to advertise an attorney's certification. Three states-Alaska, Colorado and South Carolina-permit an attorney to list himself as a specialist: (1) in recognized legal directories and law lists, (2) in a notice circulated among lawyers, (3) in the classified section of telephone directories, (4) on professional cards and letterheads, and (5) by displaying his certificate in his office. ${ }^{163}$ New Jersey and Texas allow all the above forms of advertising except for that on professional cards, shingles, or letterheads. ${ }^{164}$ Washington limits a specialist to advertising his certification (1) in legal directories and law lists, (2) in a dignified notice circulated among lawyers, and (3) by his certificate in his office. ${ }^{165}$ Indiana has drafted no proposals concerning advertising.

\section{Plans Similar to New Mexico's Self-Designation Program}

\section{a. Oregon-A slight modification of New Mexico's approach}

The Oregon State Bar has adopted a self-designation program similar to New Mexico's with certain modifications. ${ }^{166}$ Since the Committee was wary of permitting attorneys with no objective qualifications to advertise self-designated specialties, it proposed that sections representing various fields of law be established which would be open to any interested member of the Bar. ${ }^{167}$ Criminal law is designated as one of the sections. ${ }^{168}$ The Oregon State Bar

162. Alaska Plan art. Vi(b), (c); Colorado Plan rule 6(b), (c); Indiana Plan rule 12(2)(3); South Carolina Plan rule 6(a); Texas Plan rule ViI; Washington Criminal law Standards rule $\operatorname{VII}(\mathrm{B})(\mathrm{C})$.

163. Alaska Plan art XiI; Colorado Plan rule 12(b); South Carolina Plan rule 12 (c).

164. New Jersey Plan rule 9(b); Texas Plan rule XII(B).

165. Washington Criminal Law Standards rule IV(G).

166. Committee on Specialization, Oregon State Bar, Proposal to the Membership of the Oregon State Bar (1976), on file with authors [hereinafter cited as Oregon Plan].

167. The Committee stated that the adoption of standards for specialization was not practical in Oregon for the present, but it is the projected goal of the committee to eventually develop standards for various areas of the law. Committee on Specialization, Oregon State Bar, Report to the Membership-on Specialization and Advertising 1, on file with authors.

168. Eighteen sections were initially established:

(1) Admiralty

(2) Antitrust-Unfair Trade Law

(3) Appellate Practice

(4) Debtor-Creditor

(5) Civil Rights

(6) Business Law

(7) Criminal Law

(8) Estate Planning and Administration

(9) Family and Juvenile Law

(10) Zoning and Land Use Law 
will maintain lists of the membership of each section and will furnish these lists to members of the public upon request. ${ }^{169}$ The classified section of telephone directories will contain, in addition to information about the Lawyer Referral Service programs, names of the various sections and information concerning the availability of the names of lawyers enrolled in any given section. ${ }^{170}$ The Committee felt that the public would thereby have information available on the particular interests of lawyers without being exposed to distorted claims of specialization. ${ }^{171}$

\section{b. New Mexico plus CLE}

The Specialization Committees in Florida, Minnesota, Oklahoma, Nevada, Idaho, New Hampshire, and Nebraska, convinced that the members of their state bars were not ready to embark on a specialization plan which had strict requirements, opted for New Mexico's approach as an initial means to introduce specialization in their respective states. ${ }^{172}$ All seven states were concerned over the fact that New Mexico had no requirements other than selfdesignation. The major difference in these plans and the New Mexico plan is

(11) Labor Relations Law

(12) Patent, Trademark and Copyright Law

(13) Trial Practice

(14) General Practice

(15) Securities Regulations

(16) Taxation

(17) Workmen's Compensation Law

(18) Consumer Law

Any members of the Oregon State Bar may join as many as three sections in addition to his or her designation as a general practitioner. The sections would develop standards for specialization subject to the approval of the Committee on Specialization, the Board of Governors and the Supreme Court of Oregon. Oregon Plan, Proposal.

169. Oregon Plan, Public Information (b).

170. Oregon Plan, Public Information (c).

171. Committee on Specialization, Oregon State Bar, supra note 167, at 2.

172. See generally: Florida Plan, supra note 19; Recertification Committee, Idaho State Bar, Report filed Feb. 4, 1976 [hereinafter cited as IDaho Plan]; Executive Committee, Minnesota State Bar Ass'n, Legal Practice Designation Plan (1976) [hereinafter cited as Minnesota Plan]; Special Committee on Specialization, Nebraska State Bar ass'n, Nebraska Designation Plan (1976) [hereinafter cited as Nebraska Plan]; Specialization Commitree, State Bar of Nevada, Proposed Program in legal Specialization (1976) [hereinafter cited as Nevada Plan]; Committee on Specialization, New Hampshire Bar Ass'n, Specialization and Recertification (1976) and Committee on Specialization, New Hampshire Bar Ass'n, Report of Committee on Specialization and Recertification (1976) [hereinafter cited New Hampshire Plan and New Hampshire Report respectively]; Committee on Specialization and Recertification, Oklahoma Bar Ass'n, Oklahoma Designation Plan (1976) [hereinafter cited as OKLahoma Plan]; all the above are on file with authors. Florida and New Hampshire see self-designation as only the first step in a specialization plan and anticipate that eventually boards for each specialty will be created to set up standards for the specialty, thus moving toward the California approach. Letter from William $\mathrm{H}$. Shields, Chairman of the Florida Specialization Committee, August 9, 1976; on file with authors; Florida Plan $\S 2$; New Hampshire Plan at 4. 
that these plans provide for a mandatory continuing legal education requirement. ${ }^{173}$

Only Florida's plan has actually been implemented. ${ }^{174}$ Minnesota's plan has been approved by the Bar and is awaiting approval by the Minnesota Supreme Court. ${ }^{175}$ The Oklahoma plan has been approved by the Board of Governors, but not yet approved by the House Delegates of the State. ${ }^{176}$ Nevada has submitted its plan to the Board of Governors, ${ }^{177}$ and Nebraska has submitted its plan to the House of Delegates. ${ }^{178}$ Idaho and New Hampshire are still developing their plans. ${ }^{179}$ All of these plans, except New Hampshire's, have included criminal law as one of the designated areas of specialty. ${ }^{180}$

The Florida Plan and the Idaho plan permit an attorney to inform the public of up to three areas of law in which he practices if he (1) is a member of the state's bar, (2) has practiced law for at least three years, (3) has had substantial experience in the area of specialty during the three years preceding his application, and (4) agrees to continue his education and training. ${ }^{181}$

173. Florida Plan art. VIII \$ 10; Idaho Plan 1: Minnesota Plan rule 1l(d); Nebraska Plan 9; Nevada Plan rule 5(d); New Hampshire Plan 4; Oklahoma Plan rule 3(d); although Georgia is still studying the issue of specialization, the Committee on Specialization is directing its efforts toward a designation plan with a continuing legal education requirement. Letter from Daniel B. Hodgson, Chairman of Georgia's Specialization Committee, January 19, 1977, on file with authors. A plan similar to that of Florida has been proposed in Connecticut, but the Board of Governors has yet to take definitive action on this proposal.

174. The plan was approved on June 4,1975 by the Florida Supreme Court and it has been in effect since January 1, 1976. Out of the 12,000 actively practicing attorneys in Florida, approximately 8,000 are practicing under the plan. Letter from William $\mathrm{H}$. Shields, Chairman of the Florida Specialization Committee, Jan. 28, 1977, on file with authors.

175. The plan was passed by the Minnesota Bar Association at the State Bar Convention in June 1976. Letter from Thomas R. Thibodeau, Chairman, Minnesota Specialization Plan, Aug. 9, 1976, on file with authors.

176. Mr. James L. Hall, Jr., Chairman, Committee on Specialization and Accertification, Oklahoma Bar Ass'n, in a letter dated July 16, 1976 (on file with authors). stated that the plan did not pass the House of Delegates at the mid-year meeting, but was tabled. The committee is currently in the process of planning for hearings around the state to further evaluate the proposal.

177. Letter from Cliff Young, Chairman of the Nevada Specialization Committee, July 16 , 1976, on file with authors, and telephone conversation with Mr. Young's office on January 20. 1977.

178. Letter from John S. Zeilinger, Chairman of the Nebraska Specialization Committee, January 20. 1977, on file with atuhors.

179. Letter from Blaine F. Evans, Chairman, Recertification Committee, Idaho State Bar, July 13, 1976, on file with authors.

180. Florida Plan schedule A; Idaho Plan 2; Minnesota Plan rule 7; Nebraska Plan schedule A; Nevada Plan rule 3; see generally New Hampshire Plan; Orlahoma Plan exhibit A.

181. Florida Plan $\$ \S 3(\mathrm{a}), 4(\mathrm{a}), 5(\mathrm{a})(3)$. If the board finds that a member who has not engaged in the practice of law for three years has had specialized postgraduate education or concentrated specialized experience in a particular area of practice, and that the experience is equal to or greater than the experience he would have gained in that area from three years of practice, the board may waive the requirement in $\$ 4(a)$ and permit him to designate that area. FloridA PLAN \$ 4(b). Also, if the board finds that a member has had at least three years specialized experience or postgraduate education in an area of practice, and that the experience or educa- 
Such permission is valid for three years, and in order to obtain a three-year renewal, the lawyer must demonstrate that during the preceding three years he has devoted at least thirty hours of his time in furthering his education for each area in which he announces. ${ }^{182}$

Minnesota has the same basic requirements as Florida except that Minnesota specifically defines the term "substantial involvement," stipulating that during the immediately preceding two years the applicant must have spent at least 25 percent of his time in the field to be designated a specialist. ${ }^{183}$ If the plan continues beyond the initial trial period of three years, a lawyer who wishes to designate or continue to designate a field of practice must meet the additional requirement that he take courses in the designated field earning twenty or more credits during the preceding three year period. ${ }^{184}$

Oklahoma and Nevada differ from Florida and Minnesota in that an applicant must have practiced law for at least five years. ${ }^{185}$ Nebraska requires that an applicant have practiced law for two years. ${ }^{186}$ In Oklahoma, substantial involvement requires that the applicant have spent 25 percent of his time in the three years preceding his application in the speciality or specialties he designates. ${ }^{187}$ In Nevada the applicant must have spent 60 percent of his practice in the three years preceding his application in the specialty he designates. ${ }^{188}$ Nebraska's plan does not define substantial involvement, nor does the plan limit the number of areas that an attorney may designate. The Oklahoma plan requires that during the three years of designation the applicant must have taken 25 hours of CLE in each area of designation specified in order to be recertified. ${ }^{189}$ To be recertified in Nebraska the applicant must have devoted at least ten hours per year to approved legal educational activities for each area that he designates on his initial application. ${ }^{190}$ Nevada's is

tion is not unreasonably remote but that due to extenuating circumstances the member has not had substantial experience in the area during the three years preceding his application, the board may waive the requirements of subsection (a) and permit him to designate that area. Florida Plan $\S 4(c)$. The committee developing the Idaho plan has stated its intention to follow Florida's approach. Idaho Plan at 2.

182. Florida Plan $\$ 9(b)$.

183. Minnesota Plan rule 11(c). In addition, the applicant must not only be admitted to practice law in Minnesota but must also be a resident. He need not be a member of the Minnesota State Bar Ass'n, but must maintain his principal office for the practice of law in Minnesota. Minnesota Plan rule ll(a), (b).

184. Minnesota Plan rule 11(d). This rule provides that this requirement may be waived if the lawyer has taken a postgraduate course in the designated field within the preceding three years, or if he has written articles or books demonstrating a thorough knowledge of such field, or if for any other reason the Committee is satisfied that continuing legal education courses in that field during such period need not be a requirement.

185. Nevada Plan rule 6(d)(1); Oklahoma Plan rule 3(a).

186. Nebraska Plan at 6.

187. Oklahoma Plan rule $3(\mathrm{~b})$.

188. Nevada Plan rule 6(d)(3).

189. Oklahoma Plan rule 8.

190. Nebraska Plan at 9. 
the only plan which utilizes CLE in its initial certification process. The applicant must have taken fifty hours of CLE courses within the preceding three years before his application. ${ }^{191}$

Florida, Minnesota, Oklahoma, Nevada, New Hampshire, Nebraska and Idaho, like New Mexico, permit the specialist to advertise in law lists, and on professional cards and letterheads. ${ }^{192}$ Each state, however, has designated how these advertisements may be worded. Florida, Minnesota, and Nebraska permit a certified attorney to put beside his name only the area or areas of specialization. They expressly prohibit the use of "Practice Limited to . . .," "Areas of Practice . . .," or "Specializing in . . ." "193 New Hampshire and Oklahoma permit advertising to be in the form of "Cases accepted in the area of ...," "Practice limited to . . ," "No cases accepted in the area of . . ." or "Practice concentrated in the area of ... ."194 Advertisement in Nevada is limited to "Specializing in ...."195

The plans of Oklahoma, Florida, Minnesota and Nebraska have provided for special notices to be placed in the classified section of the telephone directory explaining what the designation of a specialty or specialties by an attorney means. ${ }^{196}$

191. Nevada Plan rule 6(d)(4). Recertification is required every two years. To be recertified each specialist must demonstrate in his application for renewal his or her compliance with the continuing education requirements set forth in the regulations regarding each particular area of specialization. Nevada PLAN rule $6(\mathrm{~g})(1),(3)$.

Nevada also provides for the limitation-of-practice alternative similar to the method utilized in New Mexico. Any active member of the State Bar of Nevada may elect to designate himself as limiting his practice by use of the words "practice primarily limited to." Use of this type of disclosure is permitted in recognized legal directories, law lists, in appropriate telephone directories or under the attorney's individual listing and following the attorney's name under his or her firm's listing, on the attorney's individual professional card, and the attorney's letterhead. In addition, participation in at least twelve hours every two years in continuing education programs related to the selected areas is required. Nevada Plan rule 5(c), (d).

192. Florida Plan art. Vill § 7(a); Idaho Plan 2; Minnesota Plan rule 13; Nebraska Plan at 8; Nevada Plan rule 6(k); New Hampshire Plan at 7; Oklahoma Plan rule 10.

193. Florida Plan art. Vili § 7(a); Minnesota Plan rule 14; Nebraska Plan at 8.

194. New Hampshire Plan at 7; Oklahoma Plan exhibit B.

195. Nevada Plan rule 6(k).

196. OKLAhoma Plan rule 9 gives the following notice:

$$
\text { NOTICE }
$$

For the General Information of the Public

Attorneys who have practiced for five years or more and who, during the immediately preceding three years, have had substantial experience and concentrated in a designated area of legal practice, are permitted, if they so desire, to so inform the public. Such listing DOES NOT MEAN that such attorney has been certified by the Oklahoma Bar Association or by any person or group as an "expert" or "specialist" in any area of law. nor does it mean that such attorney is any more expert or competent than any other attorney in such or any other area of practice. Such listing does mean that such attorney has agreed to comply with minimum continuing legal education requirements or approved alternatives.

ALL PERSONS ARE URGED TO MAKE THEIR OWN INDEPENDENT INVESTIGATION AND EVALUATION OF ANY ATTORNEY BEING CONSIDERED FOR EMPLOYMENT. 


\section{Hybrid Plans}

Arizona, Missouri, and Wisconsin have formulated proposals for specialization plans which combine facets of both the California-type certification program and the New Mexico-type self-designation program. ${ }^{197}$ These state plans reflect dissatisfaction with the rigid standards required by the California Plan, and equal disaffection with the liberality of the New Mexico pilot program. In choosing a middle road, these plans contain standards for certification stringent enough to insure the competence of specialists while reasonable enough to encourage specialization among attorneys. ${ }^{198}$ The Pilot Program in Legal Specialization of Arizona was approved by the state supreme court in February 1976, and is now nearly ready for implementation. ${ }^{199}$ However, the

This Notice is published for the benefit of the public by the Oklahoma Bar Association. Florida Plan art. VIII $\$ 11$ gives the following notice:

\section{NOTICE}

For the General Information of the Public

Attorneys who have practiced for three years or more and who, during the immediately preceding three years, have had substantial experience in a designated area of the legal practice are permitted, if they so desire, to inform the public of not more than three areas of the law in which they practice.

- Such listing DOES NOT MEAN that such attorney has been certified as an "expert" in such field of law.

- Neither does it mean that such attorney is necessarily any more expert or competent than any other attorney.

ALL POTENTIAL CLIENTS ARE URGED TO MAKE THEIR OWN INDEPENDENT INVESTIGATION AND EVALUATION OF ANY ATTORNEY BEING CONSIDERED.

This notice published by The Florida Bar, Tel. A.C. 904/222-5286, Tallahassee, Florida 32304.

Minnesota Plan rule 19 gives the following notice:

\section{NOTICE}

The designation of a field in the practice of law by any of the lawyers listed below means that the lawyer considers himself capable by experience and training to practice in that field, and that he is willing to take matters involving such field. It does not mean that such lawyer has been certified by any court, board, or committee or bar association as an expert in such field so designated.

197. See generally State Bar of Arizona, Pilot Program in Legal Specialization [hereinafter cited as Arizona Plan]; Special Committee on Specialization The Missouri Bar. Plan for Voluntary Specialization (1976) [hereinafter cited as Missouri Plan] (the above on file with authors); Committee on Specialization, State Bar of Wisconsin, Plan for Voluntary Specialization, in Specialization, Wisc. B. Bull. 7 (1974) [hereinafter cited as Wisconsin Plan].

198. Arizona Plan rule 5(e); Wisconsin Plan at 8.

199. Standing Committee on Specialization, ABA, supra note 118 , at 5.

However, the Arizona specialization program has recently stalled on the issue of examinations. Two of the three specialty areas, taxation and workmen's compensation, requested that no objective examination be included in the requirements for certification. But the Criminal Law Advisory Commission felt that an exam was necessary. The Board of Governors therefore remanded the question to the Board of Legal Specialization for reconsideration of the problem. Another interesting feature of the Criminal Law Advisory Commission recommendation is the modification of the five-year practice requirement to three years for public defenders and county attorneys. Telephone conversation with Thomas Thin nes, Chairman, Criminal Law Advisory Commission. Jan. 31, 1977 . 
inchoate plans of Missouri and Wisconsin, almost identical in structure, are still awaiting approval from their respective state bar associations. ${ }^{200}$

The three pilot programs are to be controlled and regulated by specialization boards set up by their respective state bars. ${ }^{201}$ Arizona's pilot program specifically provides for an additional advisory commission for each designated specialty area to assist in creating standards for certification and in implementing the program. ${ }^{202}$ At present, there are three designated specialty areas, criminal law, tax law, and workmen's compensation. ${ }^{203}$ The Criminal Law Advisory Commission will be composed of five persons: three defense attorneys, one public defender, and one prosecuting attorney. ${ }^{204}$ The pilot programs of Missouri and Wisconsin have not yet designated any areas of specialty, although their plans, like Arizona's provide for the addition of specialties by their specialization boards. ${ }^{205}$

Although Missouri and Wisconsin have not yet designated criminal law as a specialty area, an examination of their programs as well as that of Arizona will nevertheless be helpful to our study. Their programs, as with other pilot programs in their incipience, have set forth minimum criteria for evaluating candidates for certification in all specialty areas, including criminal law, at such time as any area is designated a specialty.

\section{a. Requirements for certification}

The state plans of Arizona, Missouri, and Wisconsin all stipulate that an applicant must be a member in good standing of the state bar and maintain his law office within the state. ${ }^{206}$ Arizona and Wisconsin require that the candidate also reside in the state. ${ }^{207}$ The pilot program of Arizona further directs that the applicant must have practiced law for five years on a full-time basis. ${ }^{208}$ Missouri's plan states that the applicant must either be engaged in actual law practice or be a lawyer-faculty member of an accredited Missouri law school. ${ }^{209}$

The focal point of the certification process in the pilot programs of these three states is the requirement of "substantial involvement" in the specialty area. All three plans define the phrase "substantial involvement" similarly to mean actual performance. The measurement of performance for each specialty will be tailored to the characteristics of the specialty and its complexity and distinction from other fields, and with a consideration of the extent and

\footnotetext{
200. Standing Committee on Specialization. ABA, supra note 118 , at 13, 21.

201. Arizona Plan rule 1; Missouri Plan rule I(9); Wisconsin Plan rule I.

202. Arizona Plan rule 4 .

203. ARizona Plan rule 10.

204. Arizona Plan rule 11 (b).

205. Arizona Plan rule 10; Missouri Plan rule IV(22); Wisconsin Plan rule IV(21).

206. Arizona Plan rule 5; Missouri Plan rule V(24); Wisconsin Plan rule V(23).

207. Arizona Plan rule 5(b); Wisconsin Plan rule V(23)(b).

208. Arizona Plan rule 5(c).

209. Missouri Plan rule V(24)(d)(i), (ii).
} 
kind of devotion necessary to produce a competent attorney in that area. ${ }^{210}$

Arizona's plan requires that the candidate show "substantial involvement" in his specialty during the three to five-year period immediately preceding his application. It suggests several criteria for evaluating certification candidates which are identical with those of other state plans, including those of Colorado and South Carolina. These criteria include (1) time spent by the applicant on legal work within the specialty, (2) the number and type of cases handled by the candidate within the specialty, (3) the time spent by the candidate teaching the law of the specialty, and (4) any combination of these factors. ${ }^{211}$

Missouri and Wisconsin require that the applicant be substantially involved in his specialty area during a period of not less than five years immediately prior to his petition for certification. The pilot programs of these two states suggest the same variety of activities that can be used as standards for certification, including (1) prior handling of legal matters in the specialty field, (2) participation as either a student or teacher in recognized seminars or equivalent programs of continuing legal education in the specialty field, (3) authorship of published articles recognized in the specialty field, (4) any additional formal education in the specialty field, and (5) any government or other employment which primarily deals with the specialty area. ${ }^{212}$

\section{b. Recertification}

The certification period in Arizona's pilot program is five years. To be recertified, a specialist must at least show substantial involvement in the specialty during the period of recognition, and demonstrate continued educational experience in the specialty area during the certification period. The precise standards of this educational requirement will be established by the board with assistance from the Criminal Law Advisory Commission. ${ }^{213}$

The state plans of Missouri and Wisconsin state that recognition of a specialist will be withdrawn if he fails within sixty days following the end of any year to provide information to the board indicating that he has devoted at least a predetermined portion of his professional time for such year to the designated specialty and has attended and/or participated in board-approved seminars or programs in the specialty area to an extent required by the board. $^{214}$

\section{c. Advertising}

Arizona's pilot program permits notice of certification in the classified section of the telephone directory, in recognized legal directories or law lists, in a

\footnotetext{
210. Arizona Plan rule 5; Missouri Plan rule V(25); Wisconsin Plan rule V(24).

211. Arizona Plan rule 5.

212. Missouri Plan rule V(25); Wisconsin Plan rule V(24).

213. A rizona Plan rule 6.

214. Missouri Plan rule V(30)(c); Wisconsin Plan rule V(29)(a).
} 
notice circulated among lawyers only, on professional cards, and on a certificate displayed in his office. ${ }^{215}$

Missouri's state plan provides that during the first three years of the Plan, a designation of a specialty practice may appear only in the classified section of the telephone directory, in recognized legal directories, on professional cards and letterheads, on office building directories, and on office doors. ${ }^{216}$

Wisconsin's plan for the initial five years of the program will permit notice of certification to be placed only in recognized legal directories and the classified telephone directory. ${ }^{217}$

\section{Other Approaches to Criminal Law Specialization}

\section{Utilizing the Legal Education. Tool}

The Clare Commission, headed by Robert Clare of the American College of Trial Lawyers, was appointed by Chief Justice Irving Kaufman of the United States Court of Appeals, Second Circuit, to consider various methods of improving the quality of advocacy in the district courts. ${ }^{218}$ The Commission is approaching specialization in a unique manner by requiring a minimum number of certain educational requirements for prospective applicants who apply for a license to practice before the United States district courts in the Second Circuit and the court of appeals in that circuit. ${ }^{219}$ The proposed standards require successful completion of courses in evidence, civil procedure (including federal jurisdiction, practice, and procedure), criminal law and procedure, professional responsibility, and trial advocacy. The hours of instruction are not specified and education outside the law school is specifically permitted. ${ }^{220}$

At the time that the Clare Committee was formulating its position, the Supreme Court of Indiana promulgated its now famous Rule 13 which lists in detail specific courses and the number of credit hours in such courses which

215. Arizona Plan rule 12(c).

216. Missouri Plan rule V(28).

217. Wisconsin Plan rule V(27).

218. Report on the Clare Committef Proposal for Rules of Admission to the Federal District Courts in the Second District, from the Committee on Admissions to the Bar. A.A.L.S., (1974).

219. Federal Second Circuit Plan: Minimum Educational Requirements for Federal Trial Adrocates from the Committee on Specialization, ABA, Report of Feb. 1975, reprinted in R. Zehnle, supra note 69 , at 40 .

220. Id.; In addition, the Commission requires that an applicant certify that he has read and is familiar with the specified laws and rules pertaining to the jurisdiction and procedure of the United States district courts, will adhere to the Code of Professional Responsibility, and has assisted in the preparation and attended or participated in the hearings of four civil or criminal proceedings in which testimony was taken on the merits of a disputed issue (two of these proceedings must have been in the federal courts). In lieu of the last requirement, the applicant may submit an affidavit that he has observed six complete hearings in which testimony was taken on the merits of one or more disputed issues, including three hearings in the U.S. District Court. 
an applicant must have taken in law school to be eligible for the Indiana bar examination. Great opposition to this rule has developed since its promulgation. A principal reason for this opposition is the fear that similar rules adopted by other states would result in a hopeless morass of conflicting educational requirements which no school could hope to meet and which would unreasonably interfere with legal education by making course offerings too rigid. ${ }^{21}$ The Clare Commission's proposals did not meet with the same strong opposition that the Indiana rule received. Professor Robert E. Keeton at the meeting of the Trial Advocacy Section of the Association of American Law schools, in December 1974, suggested that while the Indiana Rule might present some difficulties, the proposed Second Circuit Rules are far more modest and workable. He indicated that only a limited number of courses are required by the Second Circuit Rules and that most law students already include them in their studies. Further, the number of credit hours for each course is not specified, and education outside of law school is specifically permitted. Moreover, he suggested that admission to a state court is different from admission to a federal court. Typically, admission to practice before a state supreme court is the only way to be licensed to practice law, whereas the only legitimate purpose for being admitted to a federal district court is to try a case in that court. ${ }^{222}$

\section{The Legal Referral System}

Massachusetts has rejected the concepts of self-designation and state certification plans for the present. The Massachusetts Administration of Justice Committee argued that self-designation plans such as the one instituted in New Mexico have provided the public with no protection whatsoever against spurious specialists. ${ }^{23}$ In addition, members of the public often do not know what area of the law applies to their problem and so would not know which kind of specialist to approach. ${ }^{224}$ The Committee further argued that there was a danger in endorsing certification plans such as the one in effect in California since there is no necessary correlation between ability to pass an examination and competence in an area of law. ${ }^{225}$ Also, there will be a tendency to put undue emphasis on the specialist rating. ${ }^{26}$

The Committee therefore recommended a program that was later adopted by the Massachusetts Bar early in 1977. This program provided that the Bar-operated Lawyer's Reference Services be expanded as a means of deliver-

221. McElhaney, supra note 43 , at 43 .

222. Id.

223. Massachusetts Bar Ass'n. Administration of Justice Committee, Report to the Bar on Specialization 11 (1975).

224. Id. at 10 .

225. Id. at 3,4 .

226. Id. at 5 . 
ing legal services and that these programs be encouraged to develop evaluative techniques for all listed attorneys. ${ }^{227}$ Further, lawyers should be encouraged to use the services to identify specialists and thus aid clients in obtaining competent legal assistance that is not within the expertise of the referring attorney. ${ }^{228}$ The Committee reasoned that an advantage to having a lawyer choose the specialist to handle his client's problem is that a lawyer is better able to assess his client's needs. ${ }^{229}$

To complement these recommendations, the Committee urged that a roster of lawyer biographies be prepared and kept on file by members of the Massachusetts Bar Association staff. ${ }^{230}$ A questionnaire is being sent to all attorneys in Massachusetts requesting information on each attorney's legal educational background, graduate work, authorship of books and articles, clerkships, previous associations in practice, and limitations of law practice. ${ }^{231}$ This information will be on file at the Bar Association for use in the expanded lawyer referral system. ${ }^{232}$

\section{III}

\section{Problems in Criminal Law Specialization}

The emphasis of this article has been on the urgent need for competent criminal law attorneys. California, New Mexico, and the ABA Committee on Specialization each has its own unique approach for achieving this goal. The other states will have to make their own choice as to which approach they will follow. It is important to recognize four major problems which have been used as arguments against criminal law specialization: (1) the resulting rise in cost to the client; (2) the detrimental effect on the sole general practitioner; (3) the resulting lack of certified lawyers in the prosecutor's and public defender's offices; and (4) the adverse effect of having criminal specialization in rural or sparsely populated states with few lawyers. Some of these problems do not exist in designation type programs which have no realistic, meaningful objective standards for competence. However, if a state bar institutes a certifi-

227. Id. at 12 .

228. Id.

229. $I d$, at 10 .

230. Letter from Laurence Locke to Carl Mordechi, June 30, 1976 (on file with authors).

231. Subcommittee on Lawyer to Lawyer Referral Directory, Mass. Bar Ass'n, Report of Nov. 29, 1976 (on file with authors).

232. The D.C. Bar has a program similar to that of Massachusetts which provides for both a lawyer register and a lawyer directory. The lawyer register is based on forms filled out by the attorney. These will be kept on file at the bar offices and made available to the public on request. The lawyer directory is a yearly compendium of the information listed in the lawyer register and is available to the public. The lawyer register form contains nineteen questions to be answered, including type of law practice, fee for initial office consultation, schools attended, academic honors, client references, and a short summary of education and experience. District of Columbia Bar, Lawyer Register/Directory Explanation and Instructions 1976, on file with D.C. Bar. 
cation type program in a quest for obtaining high-quality specialists, it must face the consequences of the rigidity of its standards.

The increased cost to the middle class client has been a frequent argument against criminal law specialization. ${ }^{233}$ Since the California plan designates not merely competent attorneys but only specialists who can meet the stringent standards for certification, a small, elite group will be certified criminal law specialists. ${ }^{234}$ It will be natural for these attorneys to value their expertise above the attorneys who do not have the stamp of approval by the state bar and their fees will reflect this fact. The rich will be able to afford these "experts," and the poor will continue to rely as before on public defenders and court appointed attorneys. The middle class will be unable to afford this private criminal law specialist. Their alternatives will be to rely on court appointed attorneys or public defenders, or to depend as before on chance to find a competent but uncertified lawyer. The criticism that specialization results in increased cost is not as clearly valid when made against the ABA plan. Under the ABA plan, more attorneys will be certified since the standards for certification are designed to select those attorneys who are competent and not just those attorneys with special knowledge or experience sufficient to satisfy stringent requirements. Thus, the possibility of an expensive elite group of criminal law specialists will be undercut by the $\mathrm{ABA}$ approach.

A second criticism of criminal law specialization is that it will harm the solo general practitioner. ${ }^{235}$ Usually this type of attorney does a large volume of criminal law work, but he does not want to limit his practice to spending one-third or even one-fourth of his time in that field. Many of these practitioners may be competent criminal attorneys, but they prefer to handle a variety of legal matters. Under a rigid certification program, if the solo general practitioner wants to continue to do criminal work, he has to limit his practice in order to remain competitive with those firms and attorneys designated as specialists. However, the ABA plan affords the general practitioner the opportunity to continue in his general practice and still meet the minimum standards to qualify as competent in order to be certified.

Many question whether prosecutors and public defenders need to be certified since they handle such a large volume of criminal cases. ${ }^{236}$ The argument for certified attorneys in a public defender's office is clear. The indigent deserves to know that his attorney is as competent as a private criminal law

233. Hoffman, Legal Specialty Newest Ripoff?, Chicago Tribune, Jan. 2, 1975, reprinted in R. ZeHNLE, supra note 69 , at 43 .

234. Committee on Specialization, Criminal Justice Section, ABA, supra note 59, at 2.

235. Wright, The Role of the General Practitioner, in SPEcial Committee on Specialization, aBa, Legal Specialization 222 (1976).

236. Douglass, The Prosecutor's Viewpoint and Questions and Answers, in SPecial Committee on Specialization, ABA, Legal Specialization 230, 235 (1976). 
specialist. The public has a concomitant right to expect that the prosecutors who represent its interest be qualified. But, how can specialization be implemented in those two offices? Most prosecutor's and public defender's offices are places where neophytes right out of law school go for their training in the courtroom. They usually stay eighteen months to two years and then move on to private law practice. ${ }^{237}$ Under most proposed specialization programs, these lawyers would be precluded from qualifying as specialists because they have not practiced the requisite number of years.

Although the ABA Committee in its preliminary standards for a qualified lawyer requires five years practice, the Committee favors waiving this requirement when prosecutors and public defenders have met the other standards promulgated. The ABA has already indicated its leniency toward the special problems that are presented by these two offices. For example, it has suggested that the appellate work standard be waived if there are special circumstances preventing an attorney from appealing cases. This suggestion was made directly for the benefit of the prosecutor's and public defenders' offices since the prosecutor's office usually has a limited right of appeal and the public defenders' offices usually have separate appellate departments. ${ }^{238}$ In this way the ABA has shown its willingness to qualify prosecutors and public defenders and has been sensitive to the needs of the public when the circumstances require this leniency.

The rural areas of the country and states with sparse populations and few lawyers are hesitant about implementing specialization, even in areas such as criminal law where the clients need for competent representation is often very compelling. It is felt that specialization is incompatible with the strong need in such areas to maintain general practitioners who can handle every sort of problem. ${ }^{239}$ Many lawyers in these areas could not afford to limit a substantial part of their practice to criminal law since the volume of work would make it monetarily impractical to do so. Consequently these lawyers and their communities could ill afford to support the California specialization approach. ${ }^{240}$ The $\mathrm{ABA}$ has recognized this problem of the rural areas by stating that "many lawyers are qualified to render effective criminal law representation notwithstanding their broad areas of practice. They need not limit the majority of their clients to those involved in criminal law, nor devote a substantial part of their time to that field. This is especially true in rural areas." ${ }^{241}$

237. Id. at $235-36$.

238. Committee on Specialization, Criminal Justice Section, aba. Report of meeting held at Houston, Tex., July 9, 1976.

239. Recognition and regulation for specialization in Arkansas, 30 ARK. LAWYer 29, 30 (1975).

240. Id.

241, Commitree on Specialization, Criminal Justice Section, ABA, supra note 238, at 2. 


\section{Conclusion}

The authors agree that criminal law practice demands specialization. For specialization to meet the needs of the public and of criminal law attorneys, it must at once assure the public that the attorney who advertises that he practices criminal law is competent to do so, and it must encourage lawyers to become certified. The ABA plan makes both goals possible by requiring effective standards for certification while at the same time not making these standards overly rigid. Thus, the authors believe that the ABA's approach will be the one most acceptable to both the public and the practicing attorneys, and should therefore be fully developed and implemented. 
CONTEMPORARY PERSPECTIVES

IN CONFLICT OF LAWS 


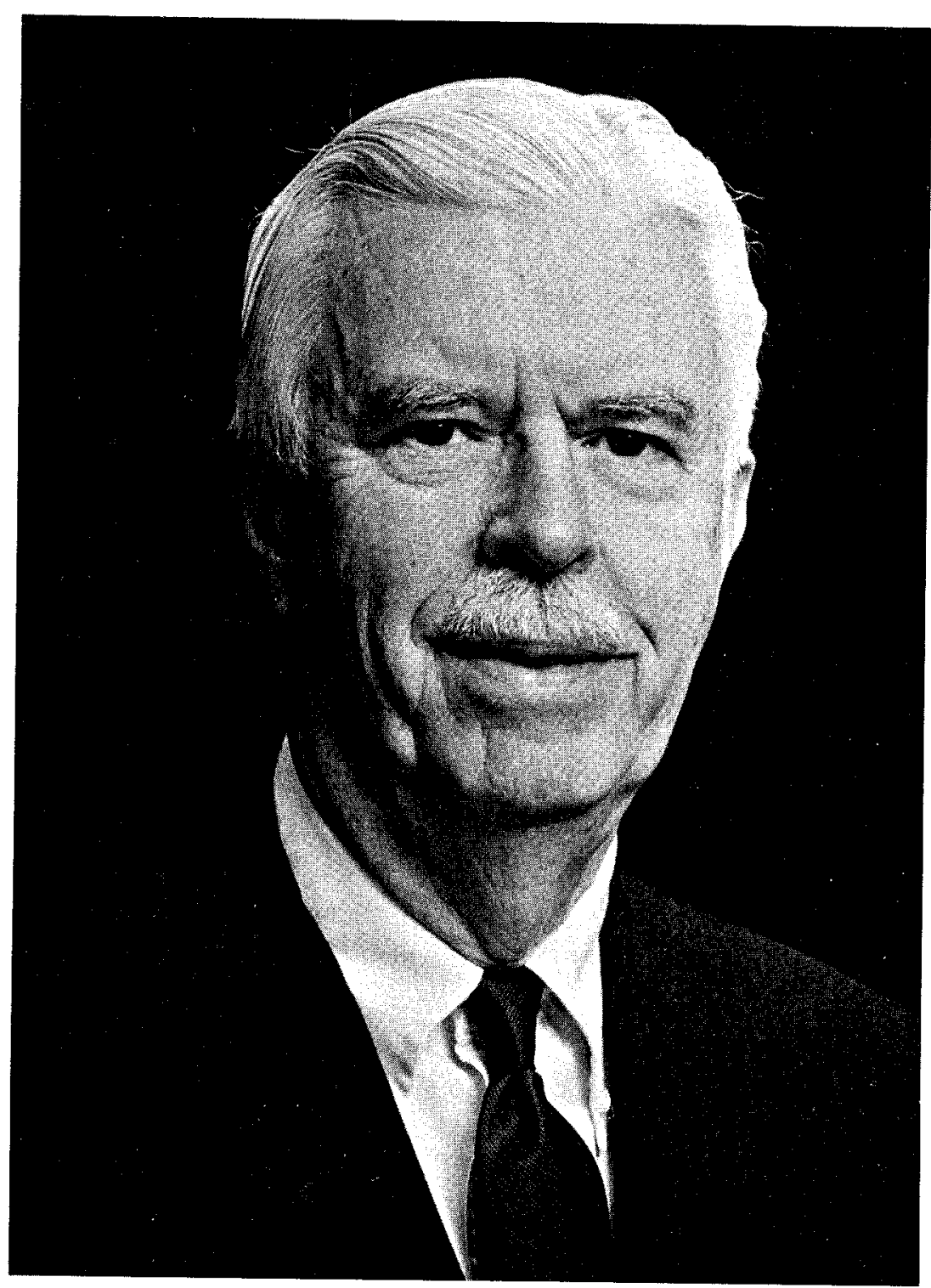

David F. Cavers 


\title{
CONTEMPORARY PERSPECTIVES IN CONFLICT OF LAWS
}

\author{
ESSAYS IN HONOR OF \\ DAVID F. CAVERS
}

\author{
EDITED BY \\ ARTHUR T. VON MEHREN, KURT H. NADELMANN \\ AND DONALD T. TRAUTMAN \\ ON BEHALF OF THE BOARD OF EDITORS \\ OF LAW AND CONTEMPORARY PROBLEMS
}

THE DUKE UNIVERSITY SCHOOL OF LAW 1977 